\title{
Exporting by Latvian companies: vitality, drivers of success, and challenges
}

\section{Tālis J. Putniṇš}

To cite this article: Tâlis J. Putniņš (2013) Exporting by Latvian companies: vitality, drivers of success, and challenges, Baltic Journal of Economics, 13:2, 5-35, DOI: 10.1080/1406099X.2013.10840531

To link to this article: http://dx.doi.org/10.1080/1406099X.2013.10840531 \section{Copyright 2013 Taylor and Francis Group}

曲 Published online: 03 Jun 2014.

Submit your article to this journal

\section{Article views: 508}

Q View related articles $\sqsubset$

4 Citing articles: 2 View citing articles 


\title{
Exporting by Latvian companies: vitality, drivers of success, and challenges
}

\author{
Tālis J. Putniņš ${ }^{1}$
}

\begin{abstract}
This paper sheds light on Latvian exporters - how active they are, what challenges they face, what makes them succeed or fail. Our study draws on a survey of 503 medium-sized Latvian companies. We find that most medium-sized Latvian companies are exporters (either directly or indirectly) and for a typical exporting company, export turnover constitutes more than half of its total turnover. Exporting companies tend to be larger, younger and faster growing than their non-exporting counterparts. They pay higher average wages, consistent with the notion that they have higher labour productivity or utilise more skilled labour on average. For a typical company, export activity has been stable over the past five years, with zero growth in export turnover and an average increase of one additional export destination; however, there is wide dispersion in export growth and success among exporting companies. Successful exporters tend to be larger, with higher productivity growth and greater innovativeness, proactiveness and risk taking, i.e., stronger entrepreneurial orientation. The main obstacle preventing non-exporters from commencing exporting is lack of international competitiveness. This is also the main reason why companies discontinue exporting, and should be the focus of policy aimed at promoting exporting.
\end{abstract}

Keywords: exports; Latvia; competitiveness; productivity; growth; entrepreneurial orientation JEL classifications: F10; F14; L25

\footnotetext{
${ }^{1}$ Department of Economics, Stockholm School of Economics in Riga (talis.putnins@sseriga.edu), and UTS Business School, University of Technology, Sydney (talis.putnins@uts.edu.au).

This paper has benefited from insightful comments by Inese Andersone, Kristīne Lomanovska, Anders Paalzow, and Andris Strazds. I gratefully acknowledge funding from Nordea and help from Arnis Sauka in arranging data collection by SKDS.
} 


\section{Introduction}

Exporting has many benefits. For a company, exporting can generate growth and profitability beyond what is possible within the confines of its domestic market. This is particularly true for companies located in relatively small domestic markets such as Latvia. For an economy, successful exporting companies can raise the international recognition and image of the country, which can have positive side effects in a number of areas such as attracting foreign investment and tourism. High exporting intensity can also help raise an economy's productivity by pushing local producers to achieve international best practices and competitiveness, specialisation of production and economies of scale. For members of society, successful exporting companies can bring about a higher standard of living through gains from international trade (wider choice of goods and services at lower prices), new jobs from increased growth rates of companies and higher real wages from increased productivity. Exporting can also be a source of risk for an economy by transmitting economic shocks from other countries (e.g., Obiora, 2009).

Despite the importance of exporting for an economy, not much is known about Latvian exporters - how active they are, what challenges they face, what makes them succeed or fail. ${ }^{2}$ The purpose of this paper is to shed light on these questions, and in particular to:

- Provide an overview of export activity in Latvia by addressing questions such as howmuch do Latvian companies export, where do they export, and how successful are they at exporting?

- Describe the characteristics of exporting companies - provide a profile of the typical exporting company in terms of size, age, growth, productivity, ownership and entrepeneurial orientation.

- Identify what makes a successful exporter by examining the associations between export success and various company practices.

- Find out what barriers and obstacles constrain the exporting activities of Latvian copanies.

- Analyse the reasons why some companies do not export and why some companies cease exporting.

Given our aims of describing the export activity of Latvian companies and providing insights for potential exporters on what business processes are associated with export success, we choose to focus on medium-sized companies that have a somewhat established operating record. Therefore, we construct a random sample of companies registered in Latvia that: (i) have annual turnover between EUR 500 thousand and EUR 50 million; (ii) were registered in 2007 or earlier; and (iii) are not from the real estate or financial sectors. With the help of data collection company SKDS we administer a questionnaire by telephone to our sample of companies and collect a total of 503 responses. The questionnaire can be found in the Internet Appendix (http://goo.gl/r2miyz).

\footnotetext{
${ }^{2}$ See Laaser and Schrader (2005) for analysis of how economic integration into the European Union has impacted the exporting practices of the Baltic countries. See Benkovskis (2012) for analysis of trends in the competitiveness of Latvian exporters.
} 


\section{Overview of export activity}

\subsection{How many Latvian companies are exporters?}

We classify our sample of 503 companies into four types according to their export activity, namely companies that: (i) export directly to other countries and do not engage in indirect exporting (Direct only); (ii) indirectly export and do not directly export (Indirect only); (iii) export both directly and indirectly (Direct and indirect); and (iv) do not export directly or indirectly (Non-exporters). Direct exporting occurs when a company sells its goods or services in another country without the involvement of a domestic third party, whereas indirect exporting occurs when goods/services are sold to a domestic third party that then subsequently exports them. The distinction is important because while both indirect and direct exporting contributes to a country's aggregate exports, companies engaged in the latter require a different set of resources and capabilities. Therefore, in some parts of this paper we will focus on different subsets of exporters, in particular, on direct exporters.

Table 1 reports the percentages of each of these four types of companies. Overall, $41 \%$ of the sampled companies are direct exporters that do not engage in indirect exporting, a further $10 \%$ export indirectly as well as directly, bringing the total percentage of firms that are direct exporters to $51 \%$. Approximately $9 \%$ of companies engage in indirect exporting only, leaving the remaining $40 \%$ of firms as non-exporters.

Table 1: Export activity

\begin{tabular}{lccccc}
\hline Category & Direct only & $\begin{array}{c}\text { Indirect } \\
\text { only }\end{array}$ & $\begin{array}{c}\text { Direct and } \\
\text { indirect }\end{array}$ & $\begin{array}{c}\text { Non- } \\
\text { exporters }\end{array}$ & $\begin{array}{c}\text { Companies } \\
\text { in category }\end{array}$ \\
\hline $\begin{array}{c}\text { All companies } \\
\text { Breakdown by sector }\end{array}$ & $41 \%$ & $9 \%$ & $10 \%$ & $40 \%$ & $100 \%$ \\
Manufacturing & $64 \%$ & $9 \%$ & $15 \%$ & $12 \%$ & $23 \%$ \\
Wholesale & $47 \%$ & $14 \%$ & $11 \%$ & $28 \%$ & $23 \%$ \\
Retail & $20 \%$ & $4 \%$ & $2 \%$ & $73 \%$ & $9 \%$ \\
Services & $31 \%$ & $5 \%$ & $8 \%$ & $56 \%$ & $31 \%$ \\
$\quad$ Construction & $5 \%$ & $0 \%$ & $14 \%$ & $81 \%$ & $4 \%$ \\
$\quad$ Other & $35 \%$ & $17 \%$ & $11 \%$ & $37 \%$ & $11 \%$ \\
Breakdown by ownership & & & & & \\
$\quad$ Domestic & $36 \%$ & $9 \%$ & $11 \%$ & $44 \%$ & $75 \%$ \\
$\quad$ Foreign & $53 \%$ & $8 \%$ & $10 \%$ & $29 \%$ & $25 \%$ \\
\hline
\end{tabular}

The numbers in the first four columns indicate the percentage of the Category's companies that: (i) export directly to other countries and do not engage in indirect exporting (Direct only); (ii) indirectly export but do not directly export (Indirect only); (iii) export both directly and indirectly (Direct and indirect); and (iv) do not export directly or indirectly (Non-exporters). The numbers in the fifth column indicate the number of companies in the Category as a percentage of the total number of companies in the sample. Foreign ownership refers to companies for which foreign companies, individuals and organisations own $50 \%$ or more of the company's shares. 
Companies' involvement in exporting differs substantially by sector. Manufacturing companies are, by a clear margin, the most often involved in exporting, with $88 \%$ exporting directly or indirectly and only $12 \%$ not exporting. They are followed by wholesale companies, of which $72 \%$ are exporters (direct and indirect). Least involved in exporting, as one might expect, are construction and retail companies, of which $19 \%$ and $27 \%$ are exporters, respectively. Approximately $44 \%$ of companies predominantly involved in services are exporters. These differences in exporting propensities across sectors are also illustrated in Figure 1.

Figure 1: Export activity by sector.

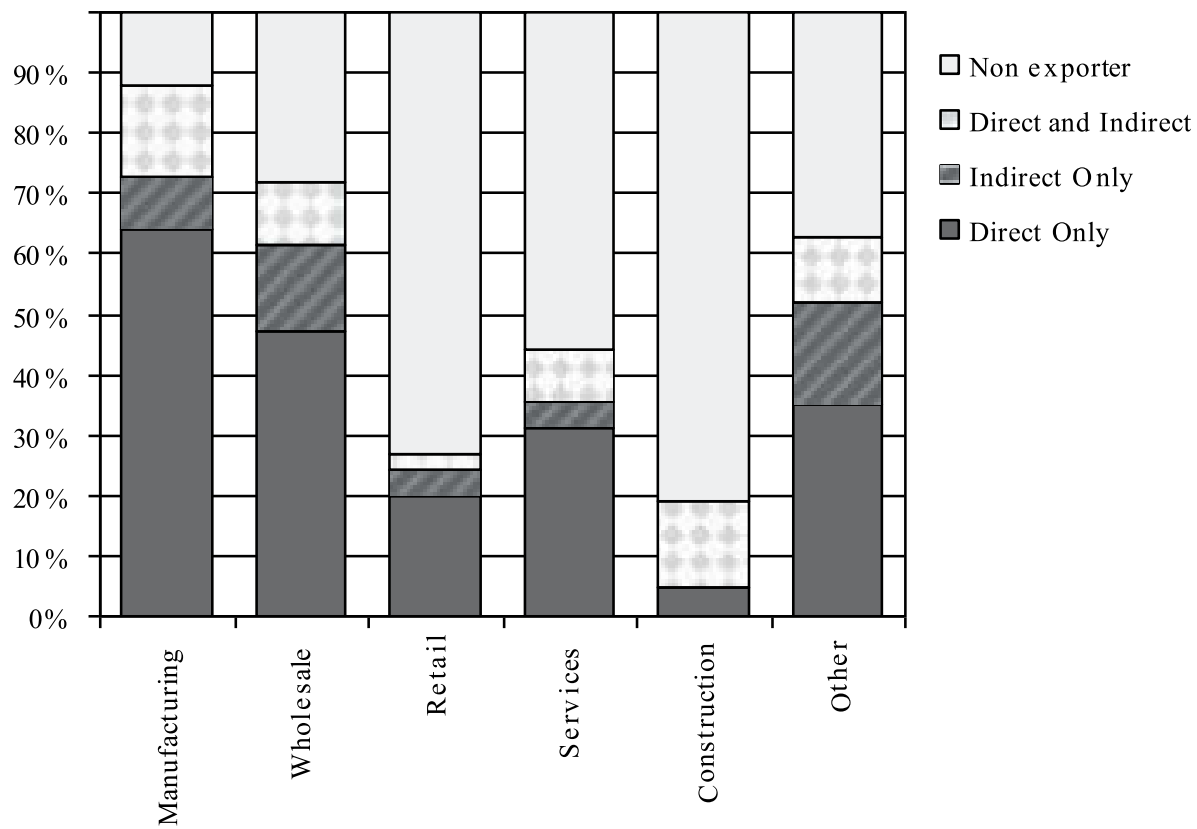

This figure shows the percentage of each sector's companies that: (i) export directly to other countries but do not engage in indirect exporting (bottom category); (ii) indirectly export but do not directly export (second from bottom); (iii) export both directly and indirectly (second from top); but (iv) do not export directly or indirectly (top category).

Foreign-owned companies are considerably more likely to be exporters compared to their domestic counterparts, with $71 \%$ of foreign-owned companies exporting, compared to $56 \%$ of domestic-owned companies. The difference is driven mainly by foreign companies being more likely to engage in direct exporting. These differences by ownership type are also illustrated in Figure 2.

While the comparisons by sector and by ownership above are useful in understanding what types of companies are more likely to be exporters, they do not directly tell us anything about the composition of sectors or ownership types among exporting companies. For example, while foreignowned companies are more likely to be direct exporters compared to domestic-owned companies, most directly exporting companies (69\%) are domestically owned reflecting the fact that a considerably higher proportion of companies in general are domestically owned. This is illustrated 
in Figure 3. By sector, approximately one third of all direct exporters operate predominantly in the manufacturing sector, approximately one quarter are wholesale companies, one quarter are services companies, and the remaining $16 \%$ are from retail, construction, and other sectors.

Figure 2: Export activity by domestic/foreign ownership.

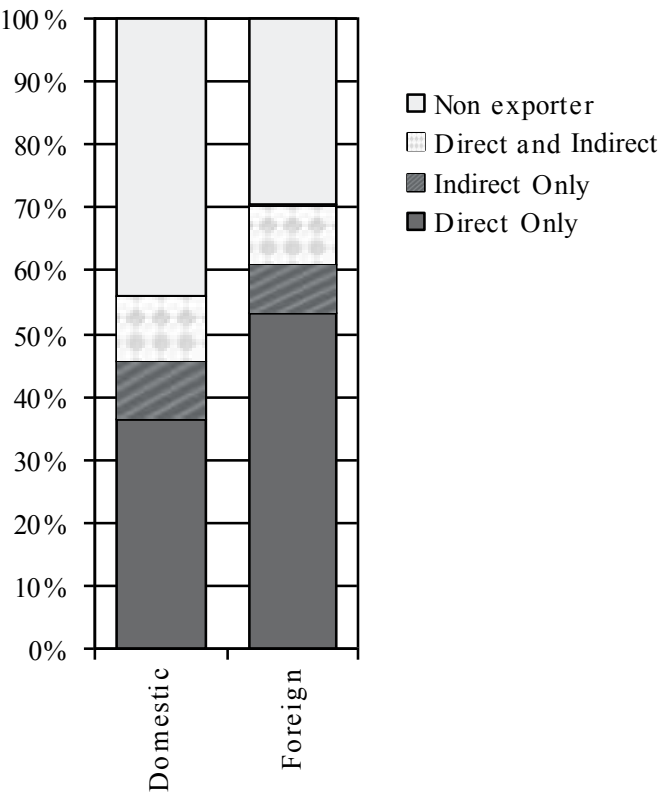

This figure shows the percentage of majority domestic owned and majority foreign owned companies that: (i) export directly to other countries but do not engage in indirect exporting (bottom category); (ii) indirectly export but do not directly export (second from bottom); (iii) export both directly and indirectly (second from top); and (iv) do not export directly or indirectly (top category).

Figure 3: Sectoral and ownership type composition of direct exporters.

Panel A: Direct exporters by sector

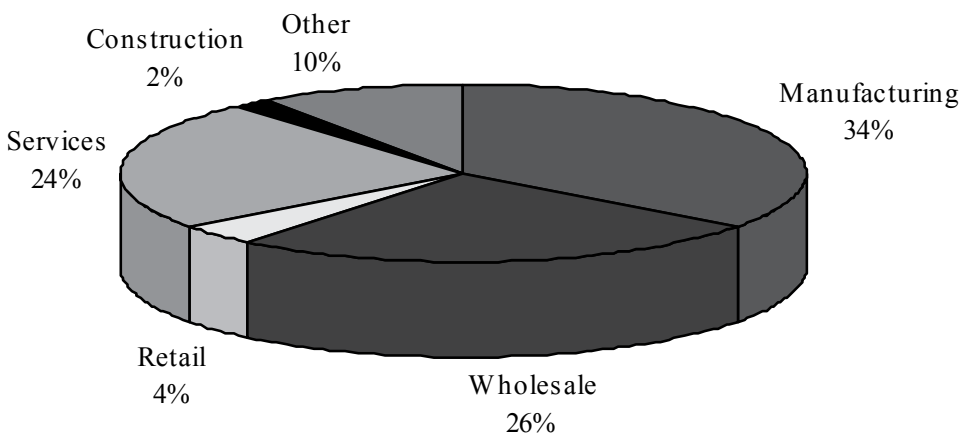


Panel B: Direct exporters by ownership type

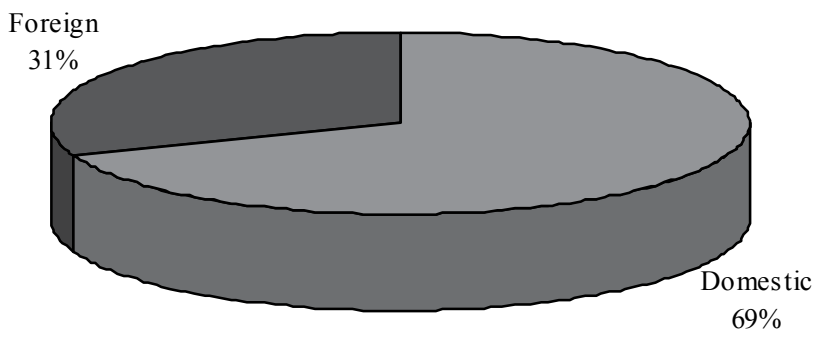

This figure shows how directly exporting companies are divided between sectors (Panel A) and domestic/ foreign majority ownership (Panel B).

\subsection{How much turnover does exporting generate?}

Across all exporting companies, export turnover on average constitutes $57 \%$ of a company's total turnover (with a median of $60 \%$ ). Figure 4 shows the distribution of export turnover to total turnover across exporting companies. For $39 \%$ of exporting companies, export turnover constitutes as much as $80 \%$ to $100 \%$ of total turnover, with the remaining $61 \%$ of companies approximately equally spread across export turnover levels from $0 \%$ to $80 \%$ of their total turnover.

Figure 4. Distribution of export turnover for exporting companies.

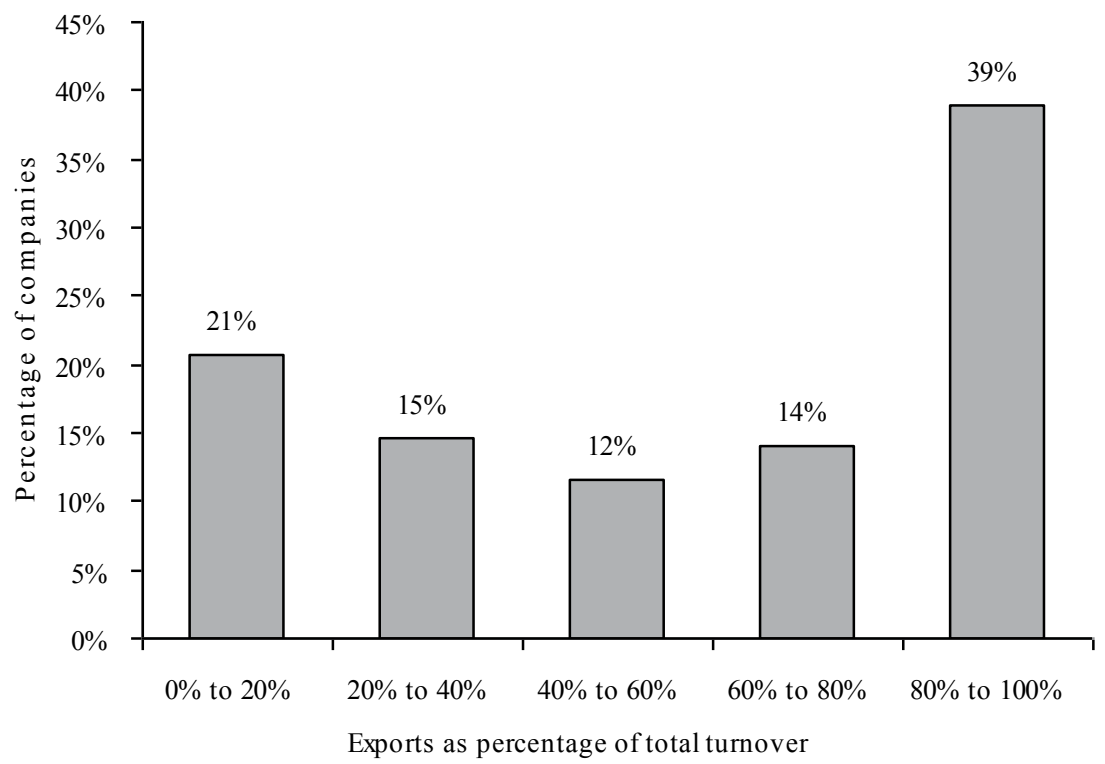

The vertical axis measures the percentage of exporting companies for which export turnover (direct and indirect as a percentage of the company's total turnover) falls within the range given on the horizontal axis. 
Figure 5 illustrates the average of exporting companies' export turnover (as a percentage of their total turnover) across sectors. Not only are manufacturing companies more likely to be exporters, but exporting manufacturing companies are more reliant on export turnover than exporting companies in other sectors, with an average of $73 \%$ of their total turnover being derived from exports. For exporting retail-based companies, export turnover constitutes an average of $23 \%$ of their total turnover, and for exporting companies in the other sectors export turnover ranges from $44 \%$ to $61 \%$ of total turnover.

Figure 5: Sector averages of export turnover as a percentage of total turnover for exporting companies.

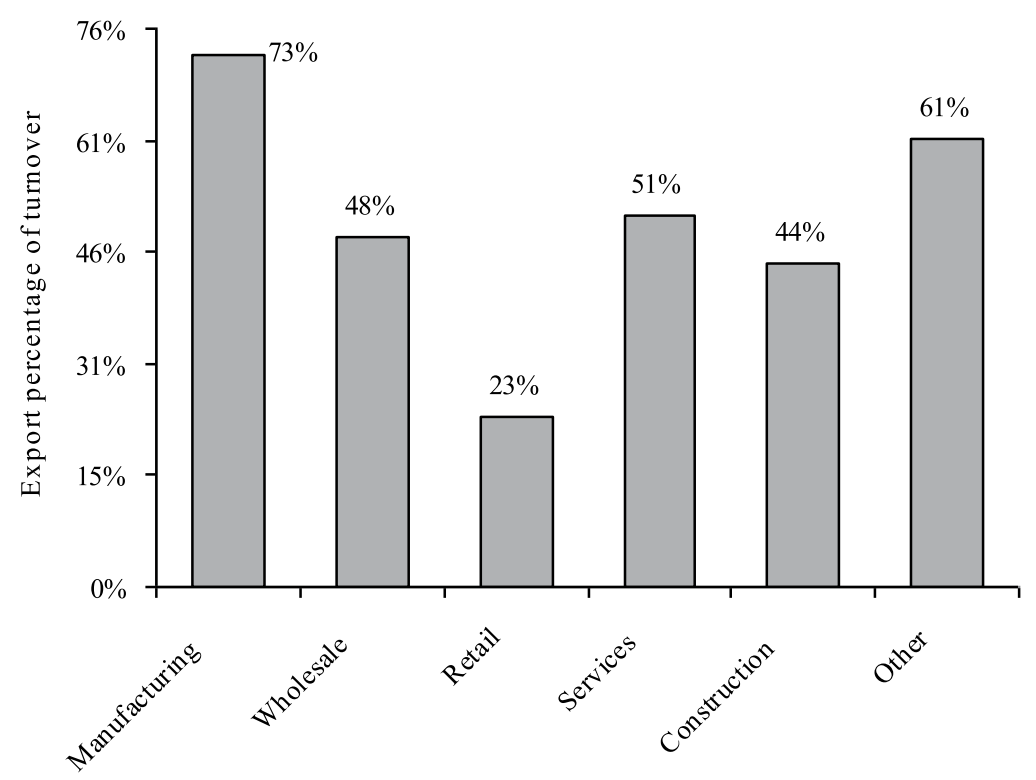

This figure shows the average of companies' export turnover as a percentage of their total turnover for all exporting companies, by sector.

\subsection{At what age do companies usually start exporting?}

On average, directly exporting companies in our sample begin exporting after 4 years of operating, although the median time to export commencement, which can be viewed as the time taken for a 'typical' company to start exporting, is 2 years. The difference between the average and median time is driven by the fact that a relatively small number of companies start exporting after a relatively long period of operation. Figure 6 illustrates the distribution of time (in years) between commencing operations and commencing exporting for companies that are currently direct exporters. Approximately one third of current direct exporters commenced exporting in the same year as the company commenced operations. 
Figure 6: Distribution of company age at export commencement.

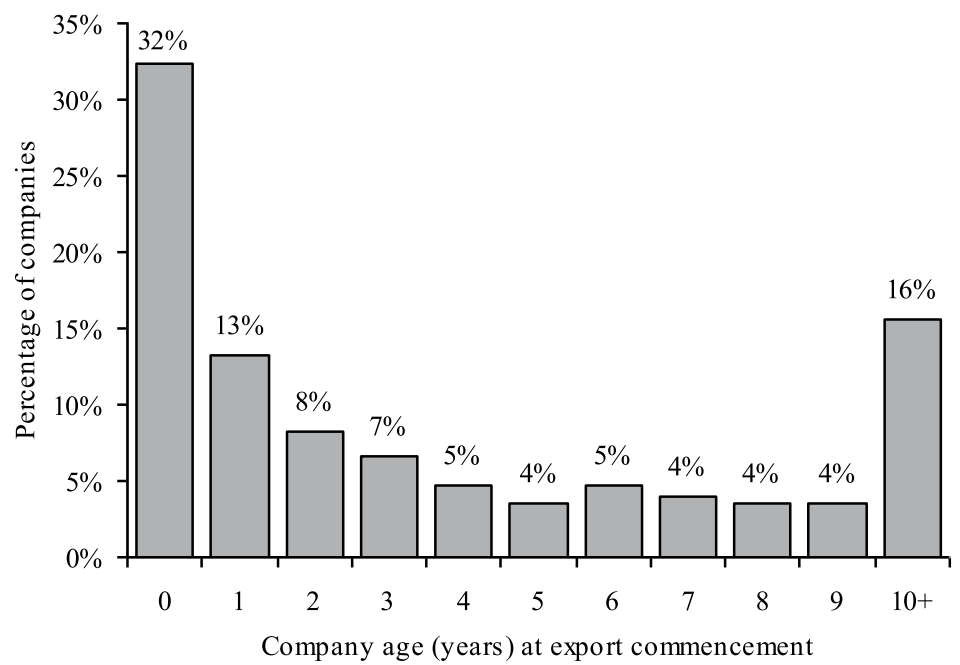

The vertical axis measures the percentage of directly exporting companies that at the time they commenced exporting had been operating for the number of years shown on the horizontal axis.

\subsection{Where do Latvian companies export their goods and services?}

As illustrated in Figure 7, the most common export destination among direct exporters in our sample is the neighbouring countries of Estonia and Lithuania, with $76 \%$ of direct exporters exporting to at least one of these two countries. Approximately $44 \%$ of direct exporters sell their goods or services in Russia, a similar number in Germany, and approximately half as many in Belarus (23\%). Approximately one half of direct exporters export to Scandinavian countries (Norway, Sweden, Finland, Denmark) and a similar number export to other EU countries not mentioned so far. Approximately 36\% export to other non-EU destinations. On average, directly exporting companies export to 7 different countries, with a 'typical' (median) company exporting to 5 different countries. The difference between the average and median again reflects the fact that a relatively small number of companies export to a very large number of countries.

Figure 8 illustrates the percentage of direct exporters that export their goods or services to: (i) the West only (Scandinavia, Germany, EU other); (ii) the East only (Russia, Belarus); and (iii) both East and West ${ }^{3}$. Close to half of the direct exporters in our sample (45\%) export only to Western countries, most of the remaining exporters do business with both the East and West (43\%), and only $12 \%$ of exporters exclusively focus on the East.

\footnotetext{
${ }^{3}$ We exclude the destinations Estonia, Lithuania and "EU other" from this analysis due to their ambiguous classification as East or West.
} 
Figure 7: Export destinations.

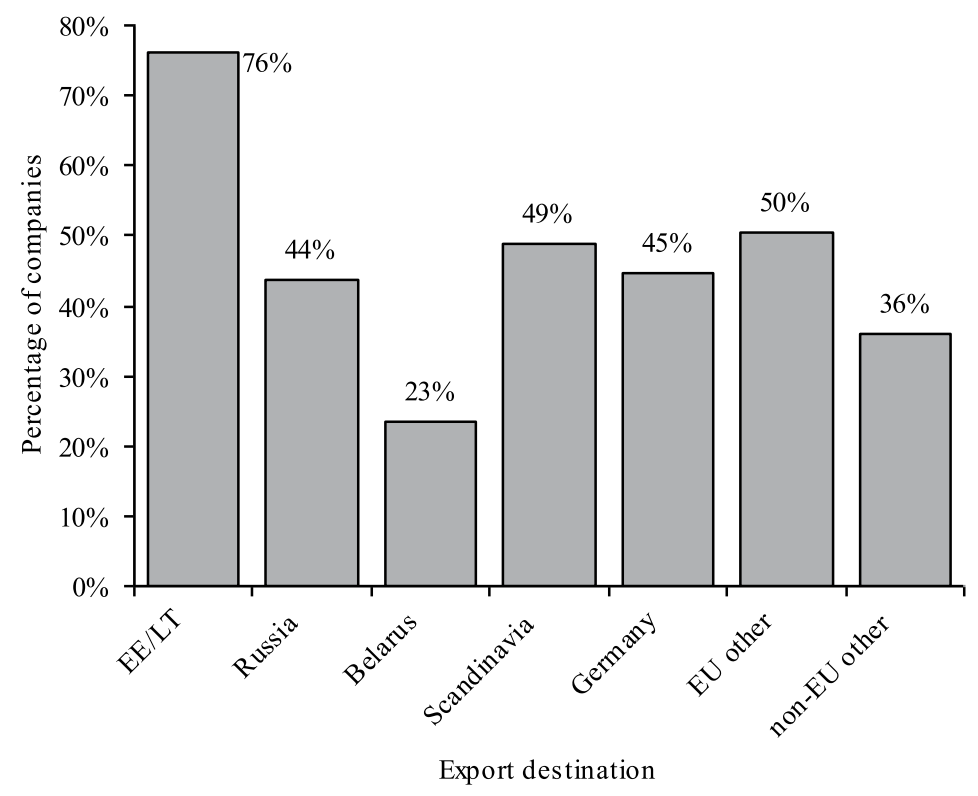

The vertical axis measures the percentage of directly exporting companies that export their goods or services to the countries/regions shown on the horizontal axis. EE/LT is Estonia and Lithuania, Scandinavia is defined as Norway, Sweden, Finland and Denmark, EU other comprises all other EU countries and non-EU other comprises all other non-EU countries.

Figure 8: East vs West export destinations.

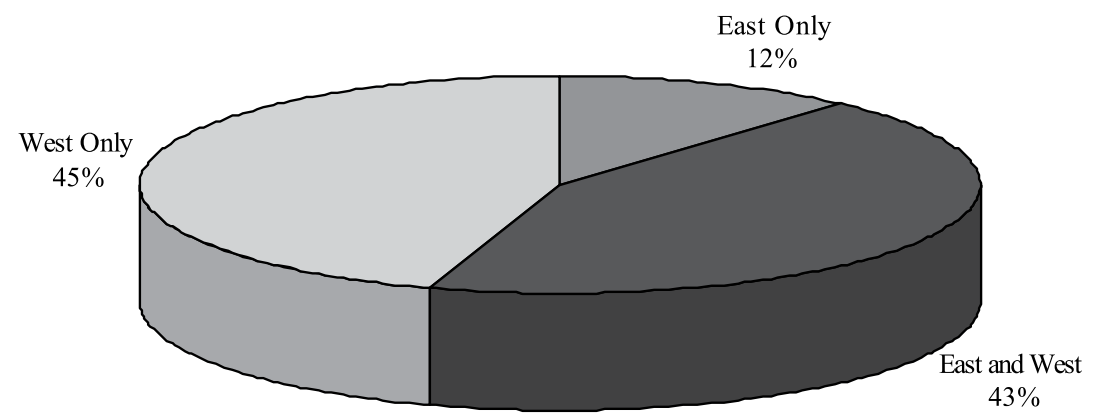

The graph shows the percentage of directly exporting companies that export their goods or services to: (i) the West only (Scandinavia, Germany, EU other); (ii) the East only (Russia, Belarus); and (iii) both East and West.

\subsection{How successful are Latvian exporters?}

What defines export success is a subjective question and many different measures of export success have been used in previous studies, most of which are based on some form of growth in export activity. For this reason we use a range of measures. The first is annualised growth 
in export turnover during the past five years. The second is growth or contraction in the number of countries to which a company exports its goods or services. The third is based on the company owner/manager's self-evaluation of the extent to which its export activity has exceeded or fallen short of its expectations over the past five years.

Average annualised growth in export revenue over the past five years for all exporting companies in our sample (that have been exporting for at least five years) is $3.5 \%$ p.a. The median is $0 \%$, i.e., a 'typical' Latvian exporting company has experienced neither growth nor decline in export turnover compared to its export turnover five years ago. These estimates are likely to be somewhat optimistic or upward biased because companies that cease exporting during the past five years or go bankrupt and cease operating altogether are not included.

Figure 9 Panel A shows the distribution of annualised export turnover growth for all exporting companies. There is considerable variation in growth levels across companies. As much as $22 \%$ of companies experienced extreme contractions of export turnover in excess of $-10 \%$ p.a. during the past five years and $27 \%$ experienced extreme growth in export turnover in excess of $+10 \%$ p.a.

While the average and median export turnover growth rates may seem somewhat low, a number of external factors such as the global financial crisis could render the rates non-representative of export performance during more 'normal' periods. For this reason comparison of export turnover growth rates of exporting companies with total turnover growth rates for all companies can help get a better estimate of aggregate export success. Across all companies, the average (nominal) annualised total turnover growth rate during the past five years is $13.1 \%$ p.a., with a median of $4.6 \%$ p.a. The distribution is shown in Panel B of Figure 9. Therefore, growth in export turnover for exporting companies has been considerably slower than growth in total turnover for all companies.

The slow growth in export turnover relative to total turnover is most pronounced in smaller companies. For example, the smallest quartile of companies has an average growth rate of $38.5 \%$ p.a. for total turnover but only $2.8 \%$ p.a. for export turnover, whereas the largest quartile of companies has an average growth rate of $4.2 \%$ p.a. in total turnover and a similar growth rate in export turnover: $4.0 \%$ p.a. These results are consistent with the more detailed analysis in the next section, which concludes that larger companies have had greater export success during the past five years. 
Figure 9: Distribution of growth in companies' export turnover and growth in total turnover.

Panel A: Growth in export turnover (all directly and indirectly exporting companies)

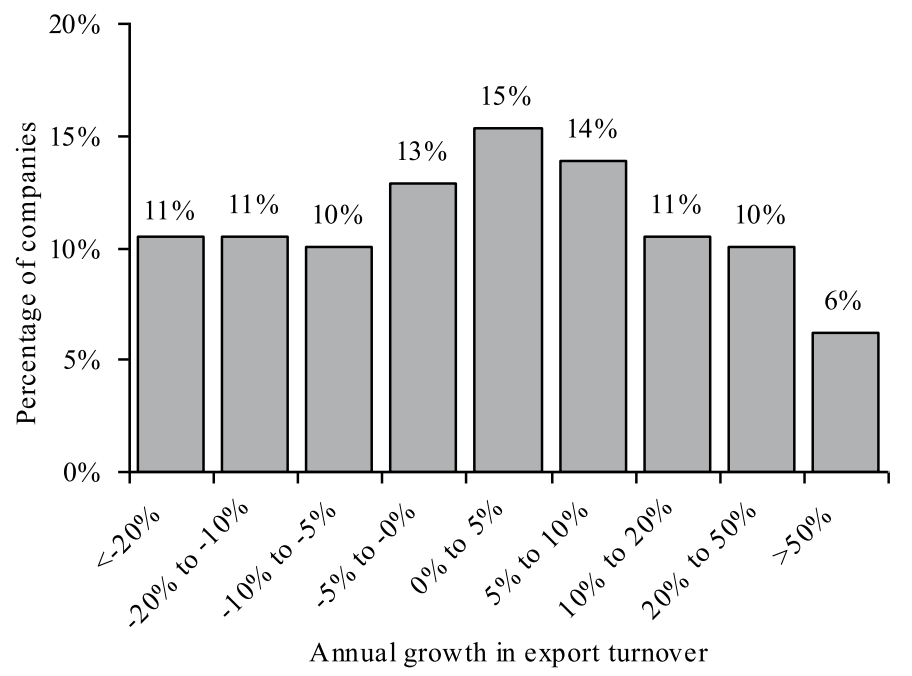

\section{Panel B: Growth in turnover (all companies)}

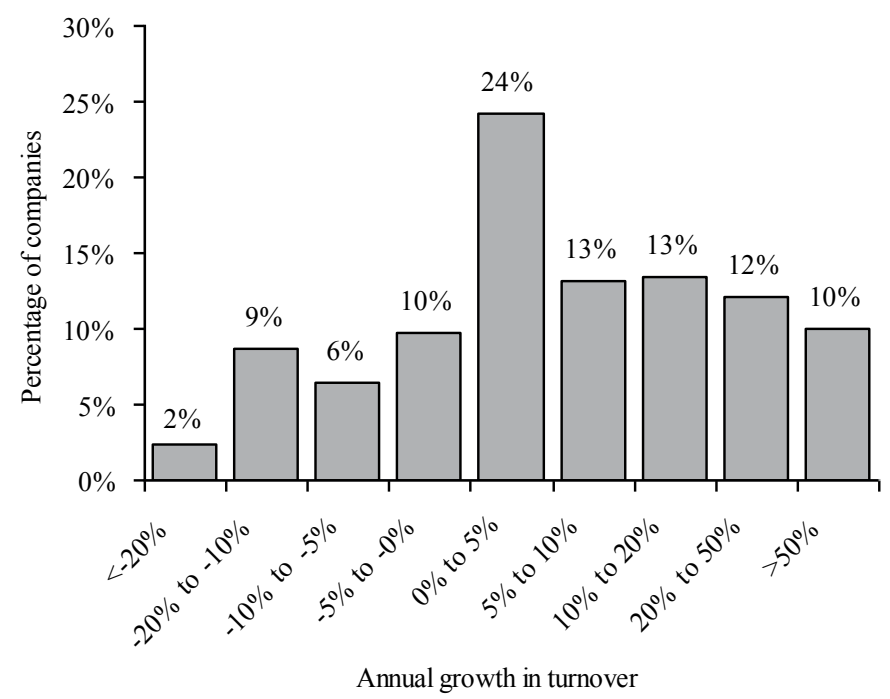

The vertical axis measures the percentage of companies for which annual export turnover growth (Panel A) and annual total turnover growth (Panel B) during the past 5 years falls within the range given on the horizontal axis. Panel A includes exporting companies; Panel B includes exporting and non-exporting companies.

On average, companies that have been directly exporting for at least five years have increased the number of countries to which they export by 2.3 during the past five years, with a 'typical' (median) company increasing its number of export destinations by one. Figure 10 shows the distribution of growth in the number of export destinations. Close to $40 \%$ of directly export- 
ing companies have neither increased nor decreased their number of export destinations during the past five years, consistent with the relatively flat average growth in export turnover. As with export turnover growth, considerable variation also occurs across companies in the changes in their number of export destinations.

Figure 10: Distribution of growth in companies' number of export destinations.

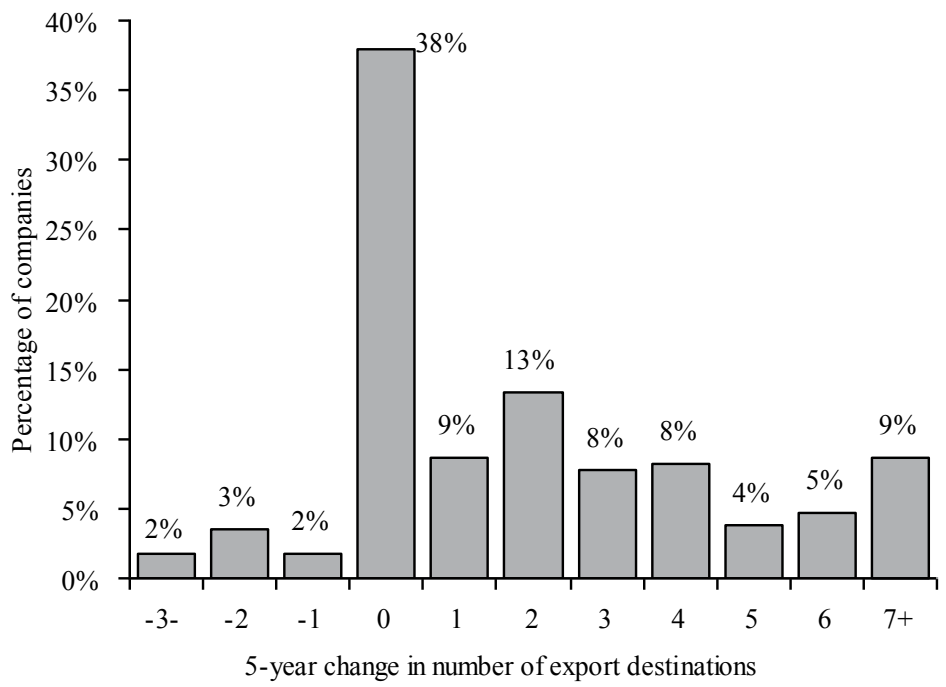

The vertical axis measures the percentage of directly exporting companies for which the change (during the past 5 years) in the number of countries to which the company exports falls within the range given on the horizontal axis. The notation $-3-$ and $7+$ indicates a value of -3 or less, and 7 or more, respectively.

For our third, somewhat more subjective measure of export success, we asked company owners/managers to compare their current actual export turnover to the export turnover that they would have forecast 5 years ago. Figure 11 shows the distribution of responses. Most often $(42 \%)$ owners/managers report that export turnover is approximately equal to what they would have forecast. Slightly more owners/managers report that export turnover exceeds forecasts $(32 \%)$ compared to those who state that it falls short of forecasts $(25 \%)$.

So where does that leave us - are Latvian exporters successful? If one believes the subjective self-evaluations of owners/managers, which are subject to a number of potential reporting biases, then Latvian direct exporters are moderately successful in the sense that they slightly more often exceed export turnover forecasts than fall short of them. However, the slightly more objective measures of export turnover growth and export destination expansion paint a picture of stagnation in export activity for a typical exporter - zero (nominal) growth in export turnover and only one additional export destination compared to five years ago. Relative to the backdrop of positive growth in total turnover for all companies (with a median of $4.6 \%$ p.a. during the past five years) this evidence suggests Latvian exporters in aggregate are not particularly successful in expanding their export activity. One thing that is clear from the results: there is wide dispersion across companies, with some very successful and some very unsuccessful exporters. 
Figure 11: Self-reported 5-year export turnover relative to forecasts.

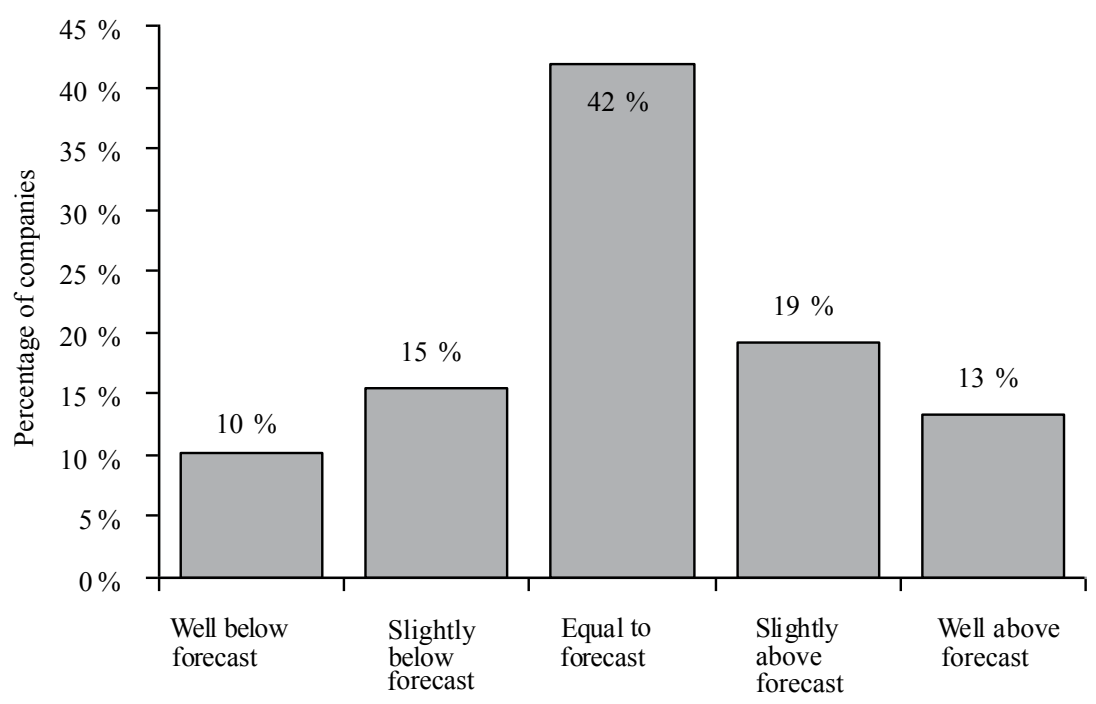

Actual export turnover relative to forecast

Company owners/managers were asked to compare their current actual export turnover to the export turnover that they would have forecast 5 years ago. The vertical axis measures the percentage of directly exporting companies for which owners/managers state actual-to-forecast export turnover correspondence in the category given on the horizontal axis.

\subsection{What are the prospects for future growth in export turnover?}

On average, directly exporting companies forecast annualised export turnover growth of $18.5 \%$ p.a. for the next two years, with a 'typical' (median) company forecasting export turnover growth of $10 \%$ p.a. Figure 12 shows the distribution of annual export turnover growth forecasts. More than one third of companies forecast growth between $10 \%$ and $20 \%$ p.a., and $10 \%$ of companies forecast export growth rates in excess of $50 \%$ p.a. Are export growth forecasts heavily influenced by managerial overconfidence, as documented by behavioural economics studies? We leave that for the reader to decide. 
Figure 12: Distribution of annual export turnover growth forecasts.

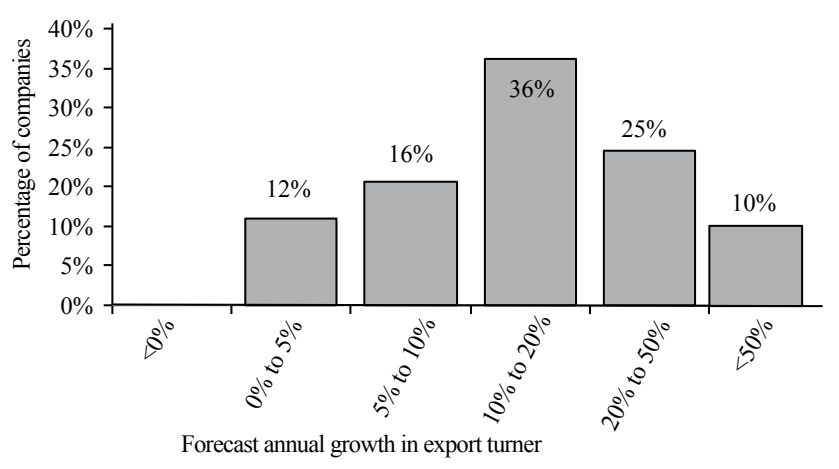

The vertical axis measures the percentage of directly exporting companies that forecast annualised export turnover growth during the next two years within the range given on the horizontal axis.

\subsection{Summary of section}

Approximately one half of the sampled companies export directly to other countries and a further $9 \%$ sell goods and services to domestic third parties that subsequently export those goods or services. Therefore, in total $60 \%$ of Latvian companies (with annual turnover between EUR 500 thousand and EUR 50 million that have been operating for at least five years) are involved in direct or indirect exporting. Manufacturing, wholesale and foreign-owned companies are more often involved in exporting. For a typical exporting company, export turnover constitutes approximately $60 \%$ of its total turnover. Typically it takes approximately two years from the time the company commences operating to the time it starts exporting, although one third of companies commence exporting in the same year as they start operating. Neighbouring Baltic countries are the most common export destination among direct exporters in our sample, and a substantial proportion of companies also export to Scandinavia, Germany, Russia, and other EU countries. A typical company engaged in direct exporting exports to 5 different countries.

Subjective self-evaluations of owners/managers suggest Latvian direct exporters slightly more often exceed export turnover forecasts than fall short of them. However, growth in export turnover and in the number of countries to which exporters sell their goods and services suggests export activity has been fairly stagnant during the past five years, with a 'typical' exporter experiencing zero (nominal) growth in export turnover and only one additional export destination. Compared to positive growth in total turnover for all companies this evidence suggests Latvian exporters in aggregate are not particularly successful in expanding their export activity. This is particularly true of smaller companies. Section 5 will attempt to identify why this is the case by examining barriers and obstacles faced by exporters. There is, however, wide dispersion in the successfulness of exporting companies, with some very successful and some very unsuccessful exporters. Section 4 will explore the reasons for this dispersion and try to identify the characteristics associated with successful exporters. 


\section{Characteristics of exporting companies}

This section provides a profile of Latvian exporting companies by describing their characteristics and contrasting them against non-exporters. Table 2 reports the means of a range of company characteristics for four export classifications: (i) non-exporters; (ii) direct exporters that do not indirectly export; (iii) indirect exporters that do not directly export; and (iv) companies that both directly and indirectly export. The table also reports tests of the statistical significance of the differences in means across the export classifications. Figure 13 graphically illustrates the differences between export classifications, and for ease of comparison all variables are scaled so that non-exporting companies have a mean and standard deviation of 100 .

Table 2: Company characteristics by export classification

\begin{tabular}{lccccccc}
\hline Variable & $\begin{array}{c}\text { 1. Non- } \\
\text { exporters }\end{array}$ & $\begin{array}{c}\text { 2. Direct } \\
\text { only }\end{array}$ & Diff $(2-1)$ & $\begin{array}{c}\text { 3. Indirect } \\
\text { only }\end{array}$ & Diff (3-1) & $\begin{array}{c}\text { 4. Direct } \\
\text { and indirect }\end{array}$ & Diff $(4-1)$ \\
\hline Turnover & 3.51 & 6.21 & $2.70^{* *}$ & 3.11 & -0.40 & 2.99 & -0.52 \\
Employees & 59.76 & 67.22 & 7.46 & 30.57 & $-29.19^{* *}$ & 43.38 & -16.38 \\
Profit & 0.15 & 0.15 & 0.00 & 0.14 & -0.01 & 0.12 & -0.03 \\
Company age & 14.28 & 13.35 & $-0.93^{*}$ & 14.14 & -0.15 & 13.54 & -0.74 \\
Turnover growth & 9.51 & 14.11 & 4.60 & 16.13 & 6.62 & 19.45 & $9.95^{*}$ \\
Employee growth & 1.29 & 5.48 & $4.19 * * *$ & 2.88 & 1.59 & 6.04 & $4.75^{* *}$ \\
Average wage & 398.95 & 466.38 & $67.42^{* * *}$ & 404.29 & 5.33 & 452.44 & 53.48 \\
Average wage growth & 2.47 & 3.05 & 0.57 & 3.25 & 0.78 & 2.52 & 0.05 \\
Change in productivity & 5.36 & 5.7 & 0.34 & 6.59 & 1.23 & 6.61 & 1.25 \\
Management education & 3.17 & 3.26 & 0.09 & 2.91 & $-0.26 *$ & 3.15 & -0.02 \\
Management experience & 13.98 & 13.81 & -0.16 & 13.91 & -0.07 & 13.65 & -0.32 \\
Number of languages & 2.68 & 3.04 & $0.36^{* * *}$ & 2.59 & -0.09 & 3.23 & $0.55^{* * *}$ \\
Innovativeness & -0.13 & 0.09 & $0.22^{* *}$ & -0.17 & -0.04 & 0.28 & $0.40^{* * *}$ \\
Proactiveness & -0.13 & 0.07 & $0.19 *$ & 0.08 & 0.21 & 0.17 & $0.29^{*}$ \\
Risk taking & -0.06 & -0.04 & 0.03 & 0.17 & 0.23 & 0.23 & $0.29^{*}$ \\
Entrepreneurial orientation & -0.15 & 0.06 & $0.20^{* *}$ & 0.04 & 0.19 & 0.30 & $0.45^{* * *}$ \\
\hline
\end{tabular}

This table reports means of various company characteristics for four export classifications, namely, companies that: (i) export directly to other countries and do not engage in indirect exporting (Direct only); (ii) indirectly export and do not directly export (Indirect only); (iii) export both directly and indirectly (Direct and indirect); and (iv) do not export directly or indirectly (Non-exporters). The columns labelled Diff report the difference in means for the export classification relative to the reference group Non-exporters, with $* * * * *$, and * indicating statistically significant differences at the $1 \%, 5 \%$ and $10 \%$ levels, respectively. Turnover and Profit are measured in LVL million per annum; Employees is the number of employees; Company age is in years since the company commenced operations; Average wage is in LVL per month; all growth variables measure annualised growth during the past five years; Change in productivity is calculated as the annualised percentage change in turnover per employee over the past five years; Management education is measured on a 4-point scale from primary or secondary school (1) through to postgraduate degree (4); Management experience is measured in years; Number of languages refers to the number of languages in which the company's employees are able to communicate with potential clients; Innovativeness, Proactiveness and Risk taking are constructed as the first principle components of a set of 7-point scaled questions relating to business scenarios; Entrepreneurial orientation is the first principle component of Innovativeness, Proactiveness and Risk taking. 
Figure 13: Comparison of direct, indirect and non-exporting companies in various company characteristics.

Panel A: First set of company characteristics

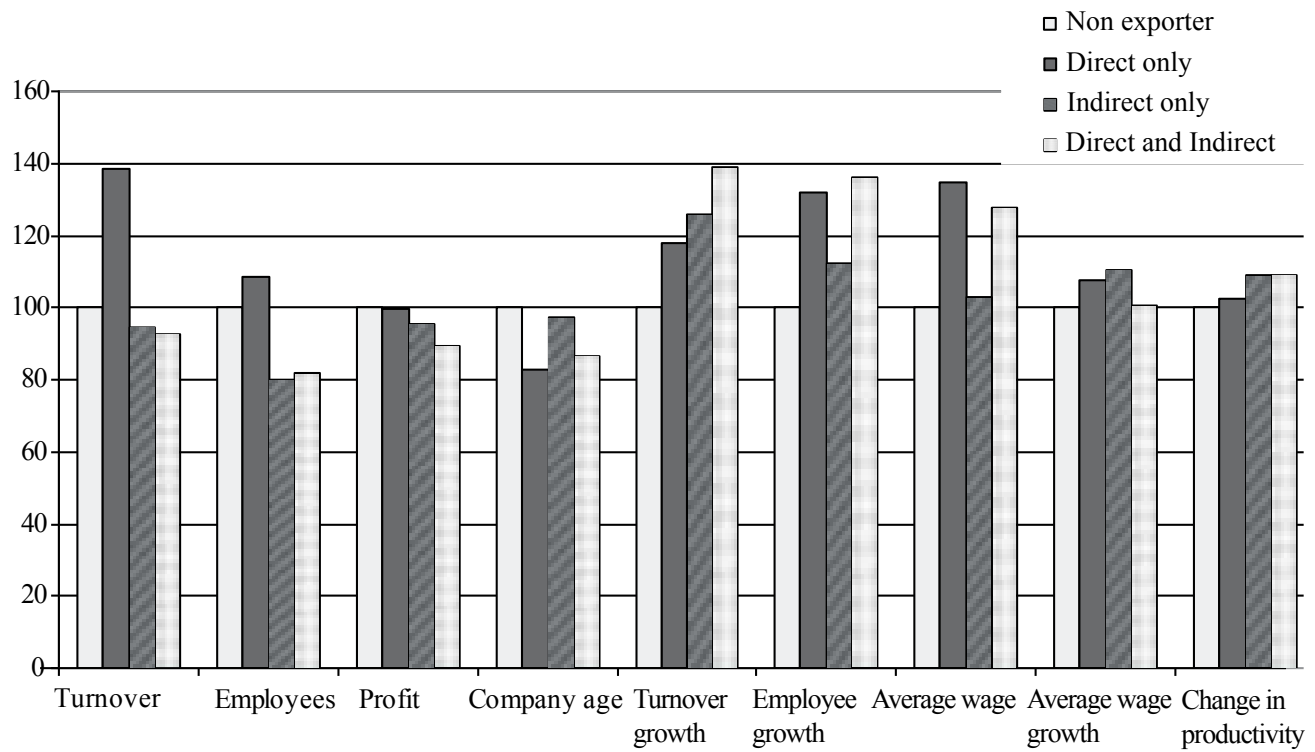

Panel B: Second set of company characteristics

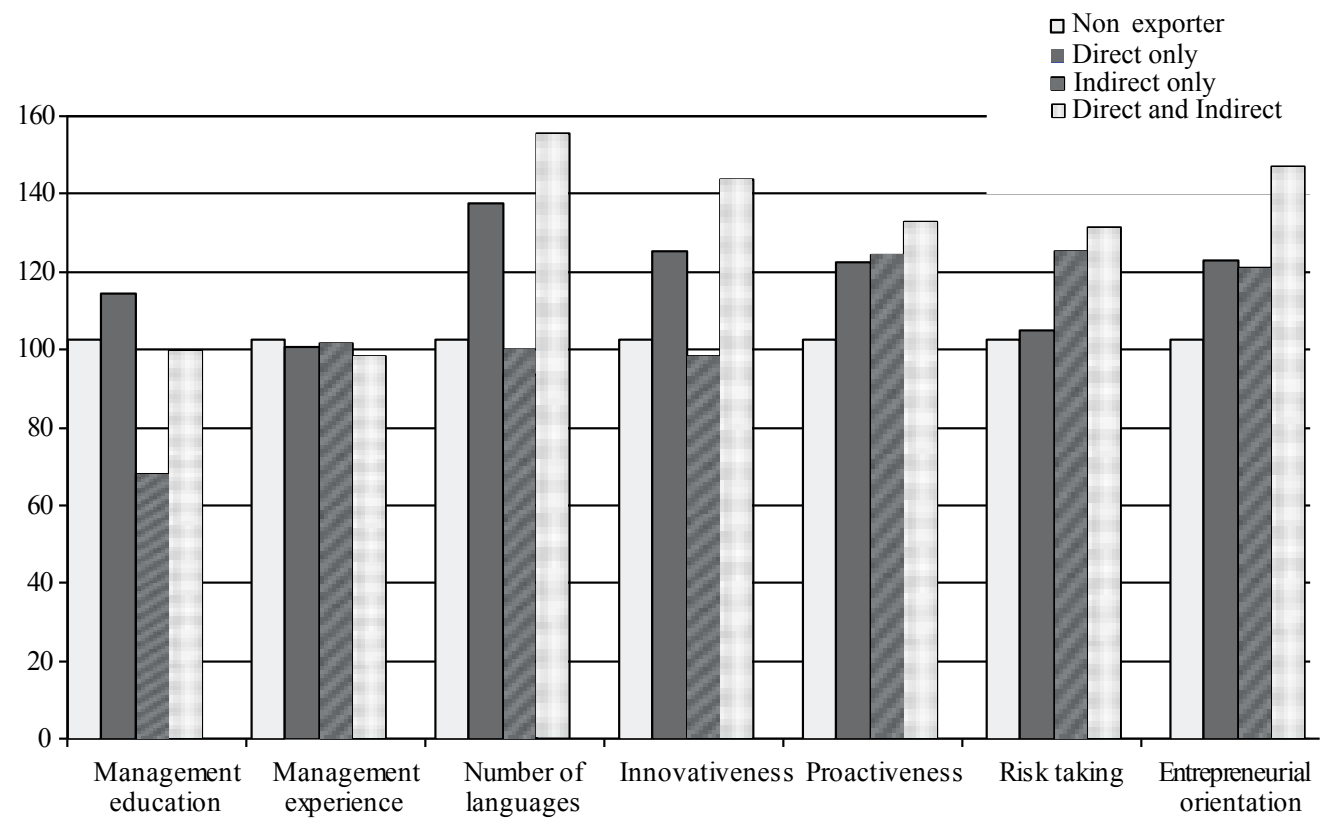

Companies are classified into four categories, those that: (i) export directly to other countries and do not engage in indirect exporting (blue); (ii) indirectly export and do not directly export (red hashed); (iii) export both directly and indirectly (green chequered); and (iv) do not export directly or indirectly (pale 
yellow). The figure plots the means of a variety of company characteristics for each exporting category. The variables are standardised so that non-exporting companies (the reference group) have a mean and standard deviation of 100 . The variables are defined in Table 2 .

Directly exporting firms tend to be larger; they have higher revenue and more employees than non-exporters (although only the former is statistically significant). The same cannot be said for companies that only indirectly export; they tend to have fewer employees. Direct exporters also tend to have higher growth rates, both in terms of turnover growth and growth in number of employees. This is consistent with the notion that tapping into other markets is a way of increasing total demand for a company's goods and services. Direct exporters also pay higher average wages, consistent with the notion that they have higher labour productivity or utilise more skilled labour on average. They also tend to be slightly younger companies.

The employees of direct exporters are able to communicate with clients in a larger number of languages. The same cannot be said for companies that only indirectly export, consistent with our earlier remark that direct exporting requires a different and probably more advanced set of business capabilities. Direct exporters, and even more so companies that engage in both direct and indirect exporting, tend to be more innovative, proactive and risk taking, and therefore have higher entrepreneurial orientation. This is consistent with many existing studies of entrepreneurship, which find that innovativeness, proactiveness, risk taking tendencies and entrepreneurial orientation are associated with better performing companies, in particular when performance is measured by growth ${ }^{4}$. Other variables, such as profit, changes in productivity, managerial experience and managerial education levels do not differ significantly between the various export classifications.

The comparison of means suggests that direct exporters are significantly different from nonexporters in a number of important company characteristics, but companies that only engage in indirect exporting in general are not particularly different from non-exporters. Therefore, we turn our focus to direct exporters and test how they differ from all other companies using a multivariate probit model that allows us to isolate differences in each individual characteristic independent of the differences in other variables. The results (not reported here) confirm many of our previous observations and can be summarised as follows. Direct exporters tend to be younger, faster growing, more innovative and possess more language capabilities, holding all other variables constant. Companies engaged in manufacturing are more likely to be direct exporters; retail and services companies are less likely.

\section{What makes a successful exporter?}

Previously we provided evidence of substantial dispersion in the successfulness of Latvian exporting companies. This section tackles the ambitious task of explaining why some companies are successful exporters but others are less successful. No single 'recipe', when followed, leads to export success. The factors that contribute to successful exporting are likely, at least in part, to be context-specific and therefore the optimal strategies may be different for different companies. The large number of existing studies of the determinants of export success has produced highly mixed findings ${ }^{5}$. This may in part be because what works in one setting (country) does not work in another, and therefore our study of the Latvian context is a novel and relevant contribution to this line of research. A further potential reason for the

\footnotetext{
${ }^{4}$ See, for example, the survey paper by Rauch et al. (2009).

${ }^{5}$ See, for example, survey papers by Katsikeas et al. (1996) and Zou and Stan (1998).
} 
mixed findings of existing studies is the difficulty in defining export success. For this reason we use several different measures of export success in this section. Given these caveats, the approach we take in this section is to try and identify what it is that successful exporters do differently from less successful ones, hopefully providing some insight into what strategies tend to work on average in a Latvian context.

We construct a list of 14 business practices that may influence export success. These practices, listed in Table 3, include factors such as strategy and planning, preparation for exporting, partnerships and visits to other countries. Some of the practices are adapted from recommendations in the Investment and Development Agency of Latvia's "Exporting Handbook" and others are derived from the findings of previous studies about practices that influence export success. We ask all companies in our sample (other than those with no desire to export) to rate the extent to which they follow each of the business practices on a scale of 1 ("strongly disagree") to 7 ("strongly agree"). In addition to comparing the extent to which successful and unsuccessful exporters follow these 14 business practices, we also compare the two types of company in various other characteristics to examine whether factors such as managerial experience, language proficiency, size, age, innovativeness, proactiveness, risk taking and so on influence export success.

Table 3: Business practices potentially associated with export success

\begin{tabular}{|c|c|}
\hline Number & Business practice \\
\hline & Long-term strategy and planning \\
\hline 1 & Company has an exporting vision and an exporting plan extending 3 years in the future \\
\hline 2 & Management has defined targets/goals for export turnover for the next 3 years \\
\hline 3 & Company has a clear strategy with regard to exporting \\
\hline 4 & $\begin{array}{l}\text { Management has clearly defined the countries to which the company would like to export in the future } \\
\text { Preparation }\end{array}$ \\
\hline 5 & Company has conducted significant research on current and potential future export markets \\
\hline 6 & Company actively monitors developments in current and potential future export markets \\
\hline 7 & $\begin{array}{l}\text { Company has arranged seminars/training on exporting for those employees that will manage the } \\
\text { exporting process }\end{array}$ \\
\hline 8 & Company has engaged professional export consultancy services \\
\hline 9 & Company has prepared marketing materials in the languages of the export target markets \\
\hline 10 & Company has adapted the product/service so that it would be optimally suited for export target markets \\
\hline 11 & $\begin{array}{l}\text { Company employees that deal with exporting have good knowledge of the languages spoken in the } \\
\text { company's current and potential future export markets } \\
\text { Partnerships }\end{array}$ \\
\hline 12 & $\begin{array}{l}\text { Company has spent significant effort in establishing relations with partners in other countries } \\
\text { Regular visits to export markets }\end{array}$ \\
\hline 13 & $\begin{array}{l}\text { Management make regular visits to the company's current and potential future export markets } \\
\text { Other factors }\end{array}$ \\
\hline 14 & Company's domestic competitors are already exporting similar products/services \\
\hline
\end{tabular}

We construct overlapping categories (i.e., not mutually exclusive) corresponding to five types of export success. Each type of export success has a corresponding reference group comprising less successful companies (or failures) to which successful exporters are compared in this analysis. The export success categories and corresponding reference groups are as follows:

(i) directly exporting companies with positive export turnover growth ( $\mathrm{n}=83$, label Turnover growth) relative to directly exporting companies with zero or negative export turnover growth $(\mathrm{n}=93)$;

(ii) directly exporting companies that have increased their number of export destinations by more than 1 in the past 5 years $(n=108$, label Destin growth) relative to those that have not $(n=124)$; 
(iii) directly exporting companies that have export turnover exceeding managerial forecasts of export turnover ( $\mathrm{n}=76$, Exceed forecast) relative to those that have not $(\mathrm{n}=158)$;

(iv) companies that have started directly exporting within the past 5 years $(n=44$, label Export start-up) relative to companies that are not currently directly exporting but would like to be $(n=45)$; and

(v) companies that have been directly exporting for the past 5 years and continue to do so $(n=212$, label Continuing) relative to those that were exporting 5 years ago but have since ceased directly exporting $(n=21)$.

Table 4 reports averages of the business practices and other characteristics for each category of export success. To allow comparison with less successful reference groups every second column reports the difference in means between the successful group of companies and the less successful reference group, and performs tests of whether the difference is statistically significant. Positive values in the difference columns suggest the successful group has a higher mean for that variable than the unsuccessful group. Figures 14 and 15 graphically illustrate the same information, with one difference: the variables are scaled so that for each export success category each variable has a mean and standard deviation of 100 for the unsuccessful reference group. Therefore, only the scaled means of the successful groups are plotted (because the unsuccessful group means are all 100 by virtue of the scaling). Therefore, values in excess of 100 indicate the successful group has a higher mean for the variable than the unsuccessful group, and vice versa. This allows an easier comparison of the magnitudes of differences across success groups and variables that would otherwise be on different scales. 


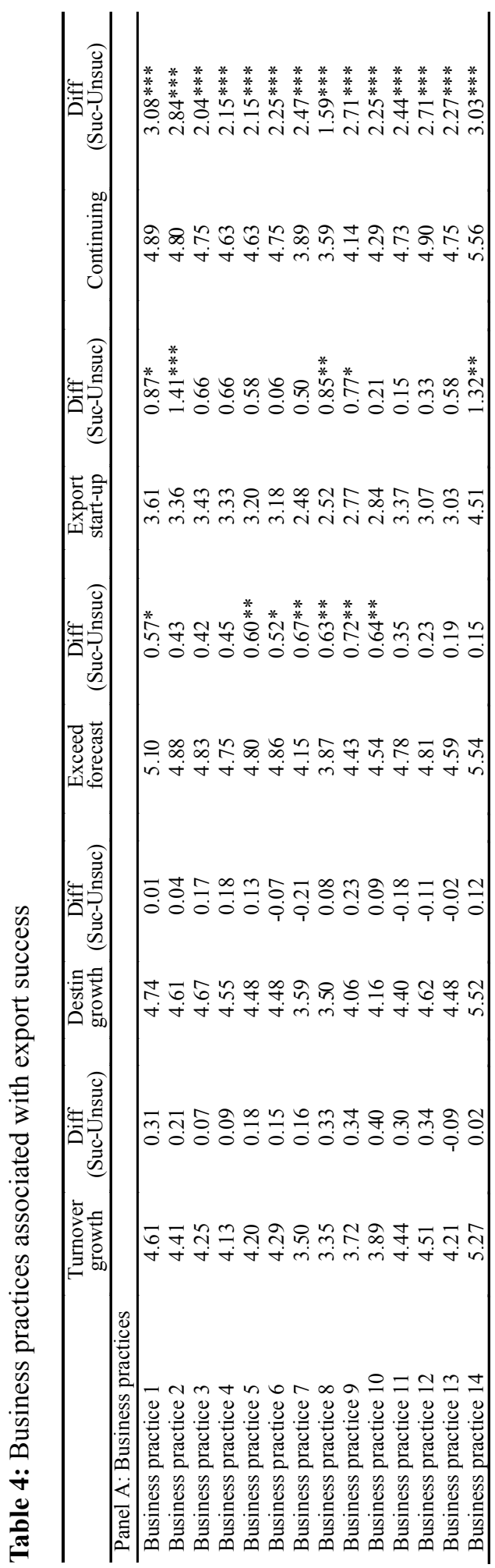

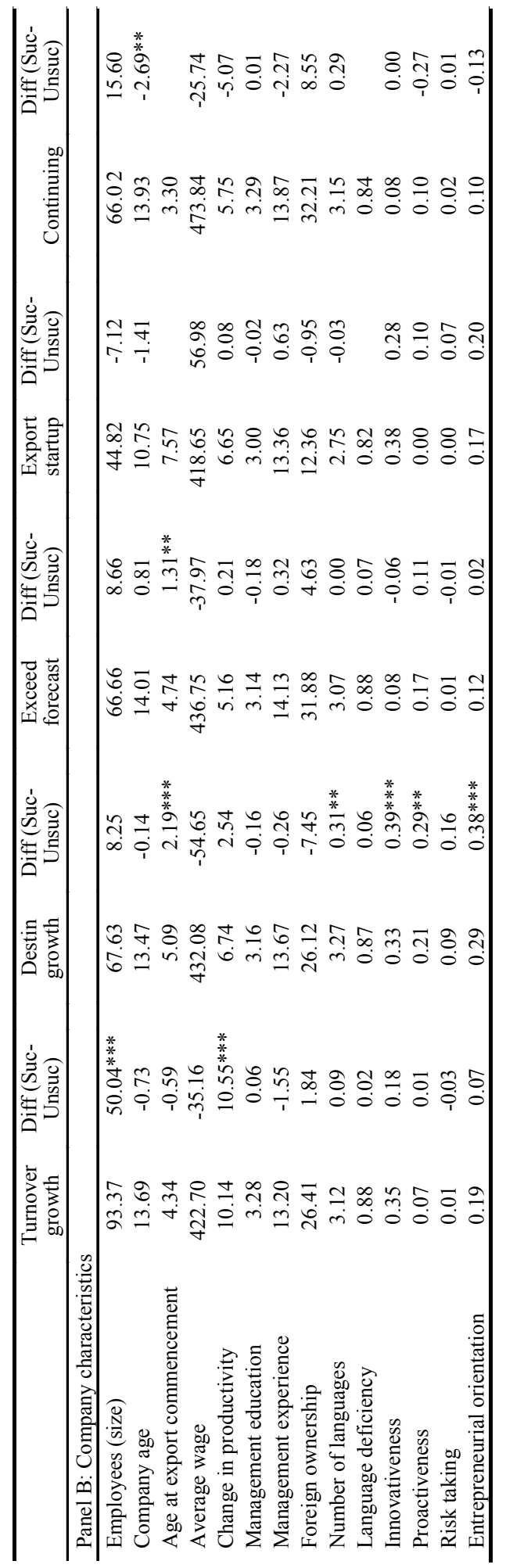




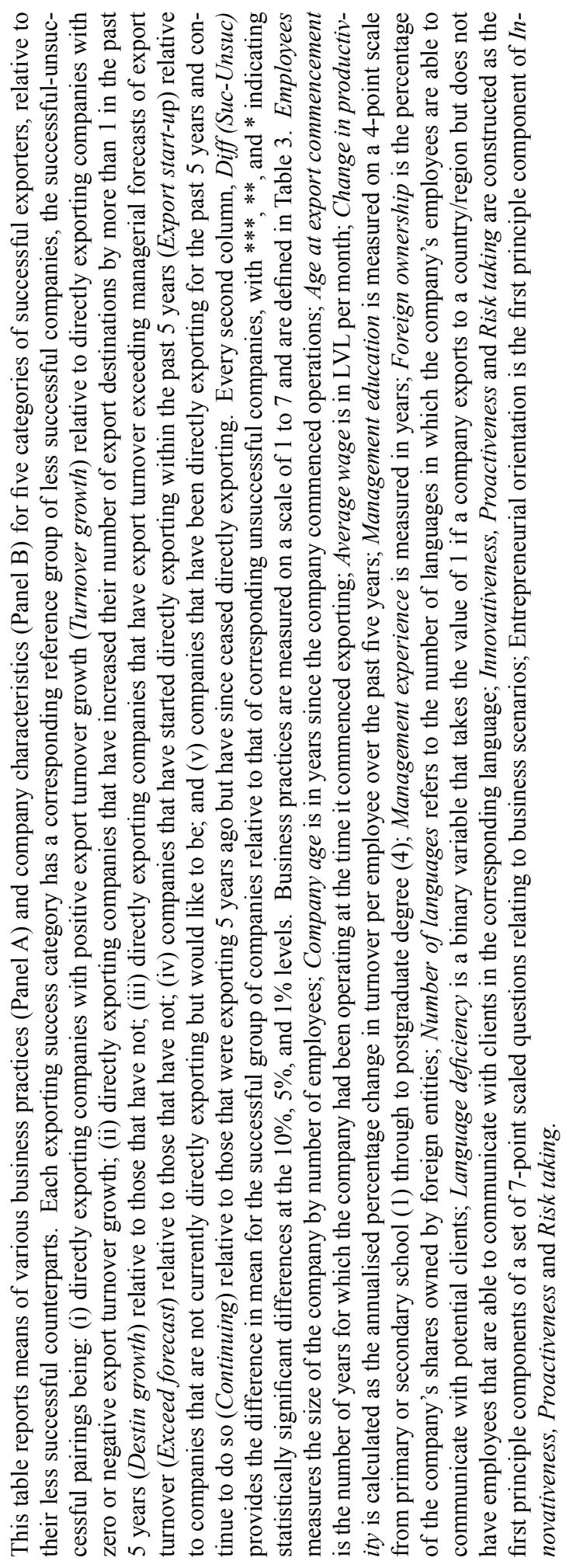


Figure 14: Business practices associated with export success.

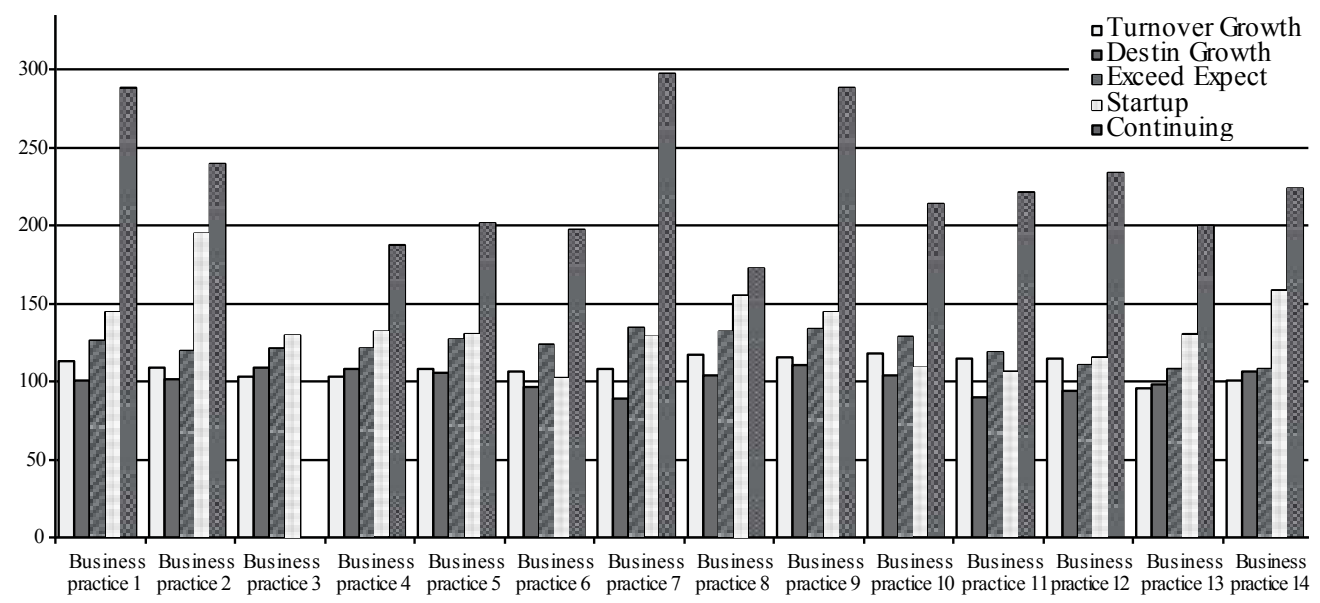

This figure plots averages of the extent to which various business practices are followed by five categories of successful exporters relative to their less successful counterparts. Each exporting success category has a corresponding reference group of less successful companies, the successful-unsuccessful pairings being: (i) directly exporting companies with positive export turnover growth (first bar; light solid) relative to directly exporting companies with zero or negative export growth; (ii) directly exporting companies that have increased their number of export destinations by more than 1 in the past 5 years (second bar; dark solid) relative to those that have not; (iii) directly exporting companies that have export turnover exceeding managerial forecasts of export turnover (third bar; hashed) relative to those that have not; (iv) companies that have started directly exporting within the past 5 years (fourth bar; chequered) relative to companies that are not currently directly exporting but would like to be; and (v) companies that have been directly exporting for the past 5 years and continue to do so (fifth bar; spotted) relative to those that were exporting 5 years ago but have since ceased directly exporting. For each successful-unsuccessful pair, all variables are scaled so that for the unsuccessful category they have mean and standard deviations of 100. Therefore, plotted values above/below 100 indicate a higher/lower mean for the successful category relative to the unsuccessful one, respectively. Business practices are defined in Table 3. 
Figure 15: Company characteristics associated with export success.

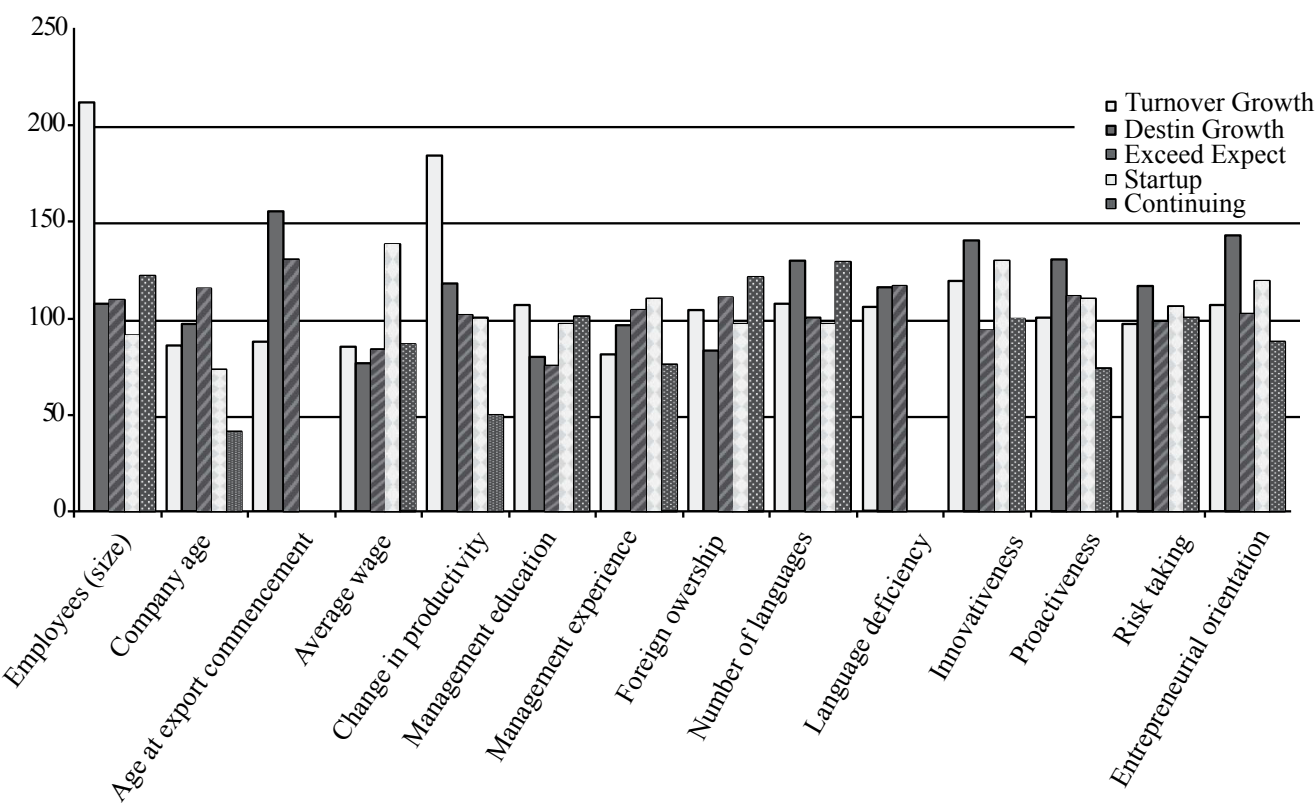

This figure plots averages of various company characteristics for five categories of successful exporters relative to their less successful counterparts. Each exporting success category has a corresponding reference group of less successful companies, the successful-unsuccessful pairings being: (i) directly exporting companies with positive export turnover growth (first bar; light solid) relative to directly exporting companies with zero or negative export growth; (ii) directly exporting companies that have increased their number of export destinations by more than 1 in the past 5 years (second bar; dark solid) relative to those that have not; (iii) directly exporting companies that have export turnover exceeding managerial forecasts of export turnover (third bar; hashed) relative to those that have not; (iv) companies that have started directly exporting within the past 5 years (fourth bar; chequered) relative to companies that are not currently directly exporting but would like to be; and (v) companies that have been directly exporting for the past 5 years and continue to do so (fifth bar; spotted) relative to those that were exporting 5 years ago but have since ceased directly exporting. For each successful-unsuccessful pair, all variables are scaled so that for the unsuccessful category they have mean and standard deviations of 100 . Therefore, plotted values above/below 100 indicate a higher/lower mean for the successful category relative to the unsuccessful one, respectively. Company characteristics are defined in Table 4.

Turning to the interpretation of the results, directly exporting companies with growth in export turnover and expansion in export destinations do not differ significantly in any of the 14 business practices hypothesised to be associated with export success, compared to those companies that have stagnant or contracting export activity. Put differently, companies with growing exports undertake export planning, preparations, overseas partnerships, and country visits to an approximately equal extent as do companies with stagnant or contracting export activity. Companies expanding their export activity do, however, differ from those with stagnant or declining export activity in other characteristics. Companies with growing export turnover or an expanding number of export destinations tend to be larger, have increasing productivity and are more entrepreneurially orientated: they tend to be more innovative, proactive and risk taking. 
Some export promoting business practices are, however, associated with export turnover exceeding managerial forecasts, i.e., with self-evaluated export success. Companies that exceed export turnover forecasts, compared to those that do not, to a greater extent tend to: (i) have an exporting vision and plan that extends 3 years into the future; (ii) conduct research on current and potential export markets as well as monitoring developments in those markets; (ii) arrange seminars/training on exporting for staff; (iii) engage export consultancy services; and (iv) prepare marketing materials and make product adaptations to suit the export destinations. Point estimates also suggest that companies exceeding turnover forecasts also follow all of the other export-promoting practices to a higher extent than other companies, although the differences are not sufficiently large as to be statistically distinguishable from zero. A sceptical alternative explanation for these results, based on behavioural economics studies, is that companies that choose to take on the significant costs associated with the aforementioned planning/research/training/marketing activities rationalise this choice ex-post by subconsciously suggesting to themselves that their export turnover has exceeded their expectations. In doing so, managers justify these costs to themselves, thereby avoiding feelings of regret for wasting resources and making poor managerial decisions.

The comparison of companies that have started exporting in the past five years to those that would like to be exporting but are not currently doing so, reveals some interesting differences. Generally, export start-ups score higher on all of the export promoting business practices, judging by the point estimates of the difference in means. In particular companies that have recently started exporting compared to those that would like to be exporting: (i) have a more developed exporting vision and plan extending 3 years into the future; (ii) have defined export targets/goals for the next 3 years; (iii) are more likely to have engaged professional export consultancy services; and (iv) have prepared marketing materials in the languages of the export target markets. Furthermore, the domestic competitors of recent export start-ups are more often already exporting similar products/services to the domestic competitors of companies intending to commence exporting in the near future. This suggests that domestic competition is a driver of export start-up, in particular when competitors start exporting.

Finally, a comparison of companies that continue to export with those that have ceased exporting during the past five years reveals some very large differences. Companies that continue exporting much more often follow the business practices advocated for exporters than companies that discontinue exporting. This does not, however, suggest that not following business practices is in any way a causal contributor to ceasing export activities. A plausible explanation for the result is that upon discontinuing exporting, for reasons which we will explore in Section 6, and becoming content with operating in only the domestic market a company no longer has the need to undertake business processes associated with exporting. This result does not, however, highlight a substantial difference between exporting and non-exporting companies in the extent to which they follow the 14 export promoting business practices.

We also analyse the determinants of export success in a multivariate framework estimating a separate probit model for each of the export success categories and using both business practices and company characteristics as explanatory variables. The results are broadly consistent with the findings we have emphasised above and therefore we do not report the model estimates. 
The results of this section can be summarised as follows: the 14 export-related business practices listed in Table 3 are undoubtedly followed to a greater extent by exporters than non-exporters, but they are not reliably associated with export success. This explains why we see a greater use of the practices by continuing exporters compared to discontinued exporters and recent export start-ups compared to companies that would like to be exporting in the near future, but no substantial differences between exporters that have growing export turnover or an expanding number of export destinations compared to those that have stagnating or declining export activity. The implication of this finding for companies that would like to start exporting in the near future or are currently exporting is that it is advisable to follow the export-related business practices, because these practices distinguish exporters from nonexporters. They will not, however, be sufficient to make the company a successful exporter.

What then makes a successful exporter? Our results suggest that successful exporters (measured in terms of positive export turnover growth or export destination expansion) are associated with increasing productivity, larger sized companies, greater innovativeness, proactiveness and risk taking, i.e., a stronger entrepreneurial orientation. Although it is not possible to provide strong evidence on causality within the framework of this study, the fact that the aforementioned characteristics are what distinguishes successful from unsuccessful exporters suggests that if companies wish to imitate the profile of a successful exporter they may consider focussing on increasing productivity, entrepreneurial orientation (innovativeness, proactiveness, risk taking), and generating growth.

\section{Barriers and constraints to exporting}

The results in Section 2 suggest that Latvian exporters in aggregate are not particularly successful in expanding their export activity. For example, the median growth rate in export turnover during the past five years is $0 \%$, compared to the median growth rate of total turnover of $4.6 \%$ p.a. Furthermore, a substantial number of companies ( $9 \%$ of our sample) would like to be exporting but are not currently doing so. This section investigates why that is the case by examining barriers and obstacles faced by exporters.

Table 5 lists potential obstacles to exporting. We ask all current exporters and all companies that would like to be exporting to evaluate the extent to which each of the items in Table 5 are obstacles to exporting or to starting to export. We measure obstacle severity using a 4-point scale from 1 ("no obstacle") to 4 ("severe obstacle"). Figure 16 plots the average responses for companies currently directly exporting (Direct exporter) and companies that are not exporting but would like to start exporting (Potential start-up). 
Table 5: Potential obstacles to exporting.

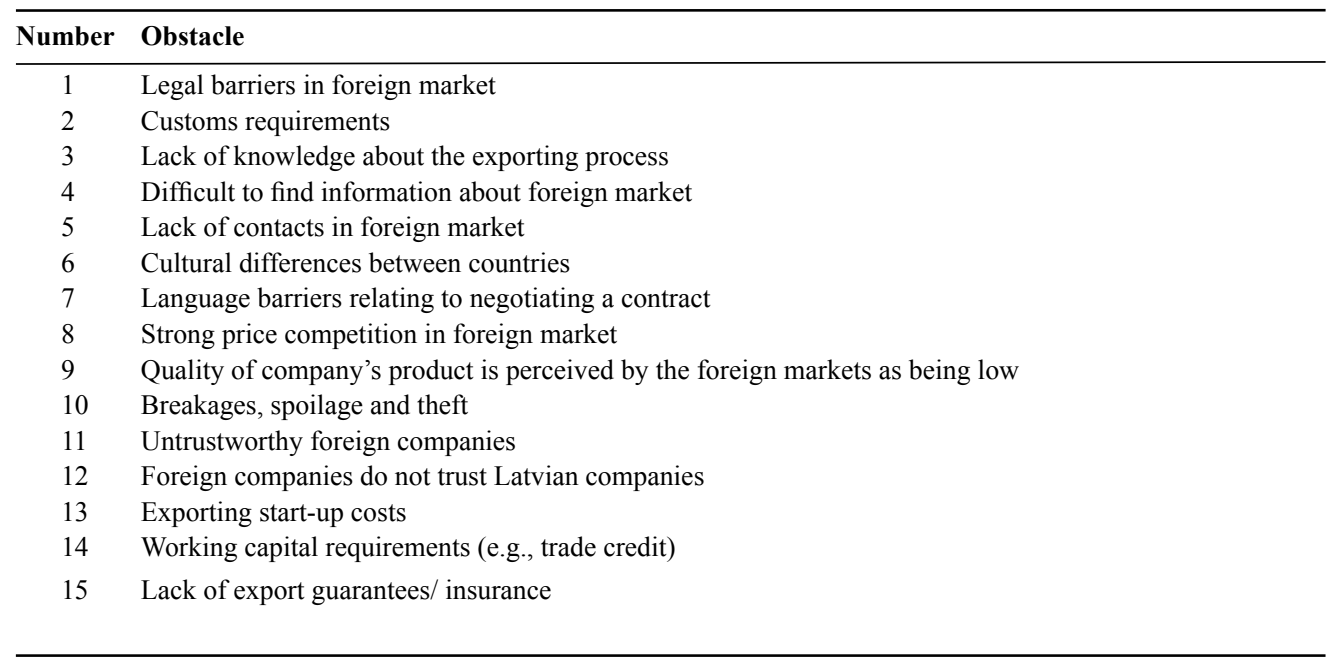

Figure 16: Obstacles to exporting.

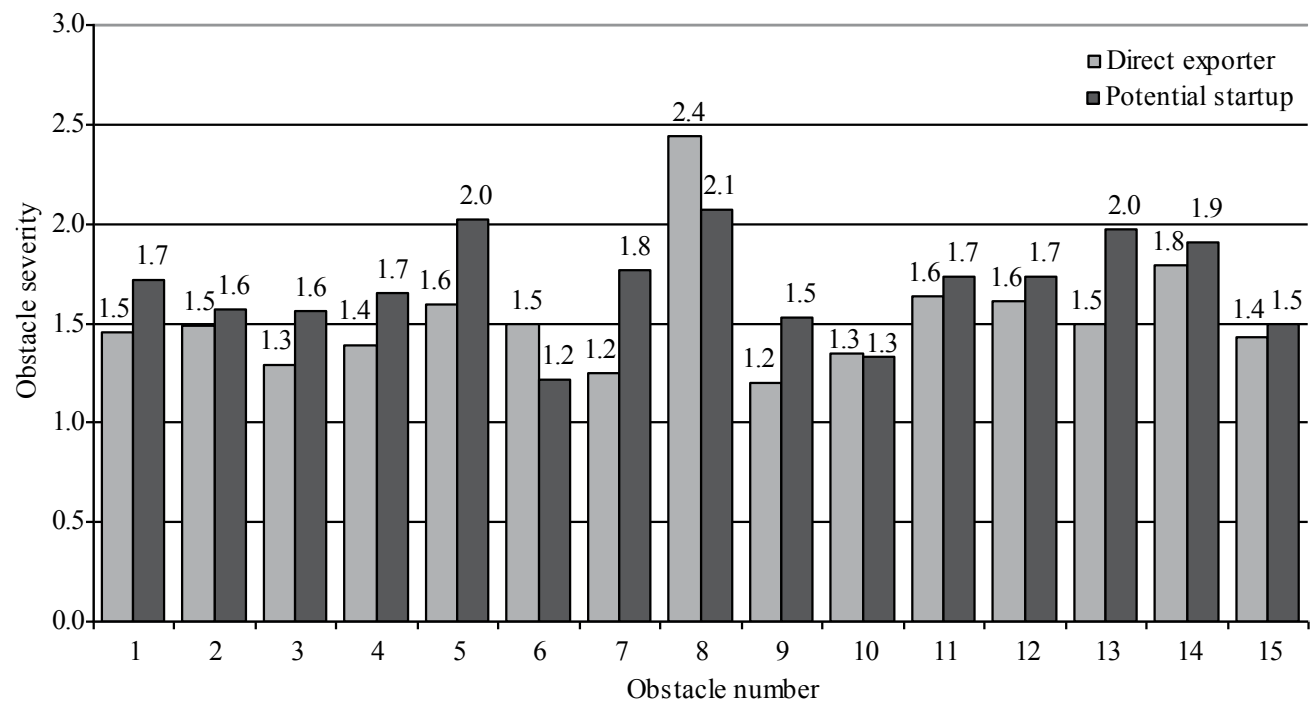

This figure plots averages of the extent to which various factors are obstacles to exporting for current direct exporters (Direct exporters) and obstacles to commencing exporting for companies that would like to be exporters (Potential start-up). The obstacles are defined in Table 5. Obstacle severity is measured on a 4-point scale from 1 ("no obstacle") to 4 ("severe obstacle").

The results indicate that, by a substantial margin, direct exporters consider the most serious obstacle to their export activity is strong price competition in the foreign market. This suggests that low international competitiveness, whether it be due to relatively low productivity or relatively high wages/prices compared to trade partners, is one of the main reasons for the lack of aggregate export growth during the past five years. This explanation is consistent with the fact that wages in Latvia have significantly outgrown increases in labour productivity during the past five years, eroding the international competitiveness of Latvian exporters. At 
one stage during the last five year period average nominal wages in Latvia were growing at a rate in excess of $30 \%$ p.a., a rate at which it is not possible to increase labour productivity.

In addition to price competition in the foreign market, other significant obstacles faced by direct exporters include: (i) working capital requirements such as trade credit; (ii) lack of contacts in foreign markets; and (iii) issues of trust - both distrust towards foreign companies and foreign companies' distrust of Latvian companies.

For companies that would like to start exporting, strong price competition in the foreign market is also the most significant obstacle. Other important obstacles that stand in their way of commencing exporting include: (i) lack of contacts in foreign markets; (ii) language barriers; (iii) exporting start-up costs; and (iv) working capital requirements. Therefore, companies that hope to start exporting in the near future face similar obstacles to current exporters, but also face the additional challenges of meeting start-up costs and building proficiency among staff members in the languages spoken in the target export markets.

In addition to the list in Table 5, some of the additional obstacles listed by companies that are worth mentioning are: (i) risk and uncertainty in the current volatile environment; (ii) political risks and unfriendly policies in the East; (iii) lack of export expertise within the company and inability to find appropriate specialists in Latvia to hire; (iv) inability to obtain bank credit to facilitate export activities; (v) expensive insurance and high costs of transport; (vi) difficulties/costs in obtaining visas; (vii) bureaucratic burden in Latvia in particular but also in some other countries; (viii) difficulty or inability in getting product quality certified in other countries; and (ix) deferred payments for goods/services.

Finally, to investigate the extent to which the obstacles impact export performance, in Figure 17 we compare the averages of obstacle severity for direct exporters that have growing export turnover and direct exporters that have zero or negative export turnover growth. In general, the pattern of obstacle severity is quite similar for the two groups of exporters, suggesting that the potential obstacles listed in Table 5 are not able to explain a significant amount of the deviation in export performance. The only statistically significant differences in perceived obstacle severity for the two groups is for obstacles 7 and 11: growing exporters feel more constrained by language barriers, possibly because they are entering new export markets, and exporters with stagnating or declining export turnover feel that untrustworthy foreign companies are a more severe obstacle to their export activity. 
Figure 17: Obstacles faced by successful and unsuccessful exporters.

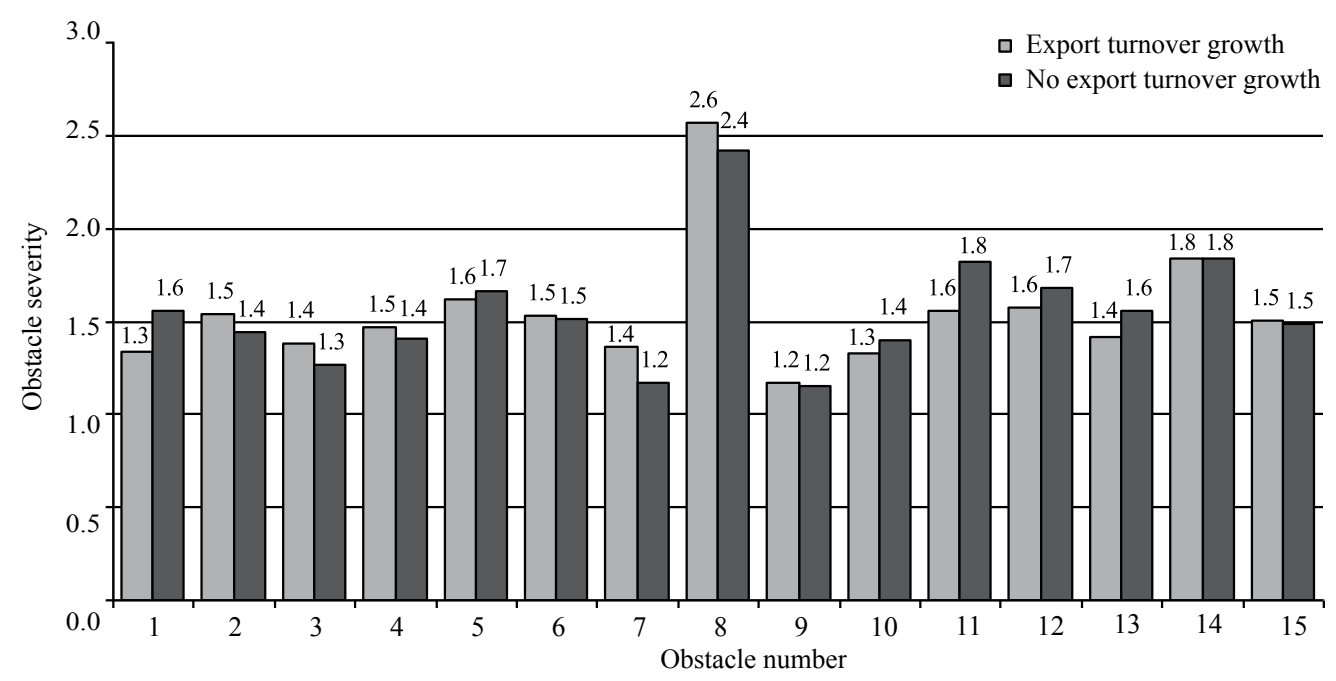

This figure plots averages of the extent to which various factors are obstacles to exporting for direct exporters that have growing export turnover (Export turnover growth) and direct exporters that have zero or negative export turnover growth (No export turnover growth). The obstacles are defined in Table 5. Obstacle severity is measured on a 4-point scale from 1 ("no obstacle") to 4 ("severe obstacle").

In summary, we find that Latvian exporters feel that the most severe obstacle to exporting is strong price competition in foreign markets. This suggests that relatively low productivity in Latvian companies or high wage/price levels compared to trade partners are likely to be significant contributors to the lack of aggregate export turnover growth noted in our overview of export activity. Therefore policymakers that place exports as a priority should focus on raising international competitiveness by, for example, facilitating further adjustment of price/ wage levels relative to trade partners or by concentrating on increasing productivity. Factors such as legal barriers, customs requirements, breakage/spoilage, and a lack of information about the exporting process or about potential export markets are considerably less significant obstacles. Companies that hope to start exporting in the near future face similar obstacles to current exporters (strong price competition, working capital requirements, lack of contacts, trust issues), but also face the additional challenges of meeting start-up costs and building proficiency among staff members in the languages spoken in the target export markets.

\section{Why do some companies cease exporting or not consider exporting?}

In our sample of 503 Latvian companies, 4\% were exporting five years ago but have since discontinued exporting, and a further $36 \%$ have never exported and have no desire to export. In this section we explore the reasons behind these export decisions.

The main reason why companies in our sample discontinue exporting is competition from companies in the foreign market (33\% of companies discontinuing exporting provide this reason). A further $25 \%$ state that the reason is increasing costs of production such as Latvian wages. Together, this suggests that the majority of companies that discontinue exporting $(58 \%)$ do so due to inability to sustain international competitiveness. This reinforces 
the results in the previous section that productivity and competitiveness are considerable constraints to Latvian exports. The other significant reason, provided by one quarter of export discontinuing companies, is legal/customs/regulatory issues. Other reasons provided by more than two companies include corporate restructuring that has changed the business focus of the company, and a change from direct to indirect exporting.

Turning to companies that have never exported, an overwhelming majority (64\%) state that they have no desire to export because their product or service is not suitable for export. The second most common reason, provided by $26 \%$ of non-exporting companies, is ample demand for their products or services in the domestic market. A smaller but not insignificant proportion $(6 \%)$ has no desire to export because there is too much competition in potential export markets. In a smaller number of cases there are more simple technical reasons such as being a subsidiary of a larger corporation and therefore not being allowed to enter other markets.

\section{Conclusions}

\section{How active are Latvian companies as exporters?}

Approximately one half of the companies in our sample export directly to other countries and a further $9 \%$ sell goods and services to domestic third parties that subsequently export those goods or services. Therefore, in total approximately $60 \%$ of Latvian companies (with annual turnover between EUR 500 thousand and EUR 50 million that have been operating for at least five years) are involved in direct or indirect exporting. Manufacturing, wholesale and foreign-owned companies are more often involved in exporting. For a typical exporting company, export turnover constitutes approximately $60 \%$ of its total turnover. For companies currently engaged in direct exporting, it typically took approximately two years from the time the company commenced operating to the time it started exporting, although one third of companies commenced exporting in the same year as they started operating. Neighbouring Baltic countries are the most common export destinations among direct exporters in our sample, and a substantial proportion of companies also export to Scandinavia, Germany, Russia, and other EU countries. A typical company engaged in direct exporting exports to five different countries.

\section{How successful are Latvian exporters in aggregate?}

Subjective self-evaluations of owners/managers suggest Latvian direct exporters slightly more often exceed export turnover forecasts than fall short of them. However, growth in export turnover and in the number of countries to which exporters sell their goods and services has been fairly stagnant during the past five years, with a 'typical' exporter experiencing zero growth in export turnover and only one additional export destination. Compared to the positive growth in total turnover for all companies this evidence suggests Latvian exporters in aggregate have not been very successful in expanding their export activity. This is particularly true of smaller companies. There is, however, wide dispersion in the successfulness of exporting companies, with some very successful and some very unsuccessful exporters.

\section{How do exporting companies differ from other companies?}

Directly exporting companies tend to be larger, younger and faster growing than their nonexporting or only indirectly exporting counterparts. This is consistent with the notion that 
tapping into other markets is a way of increasing total demand for a company's goods and services. Direct exporters also pay higher average wages, consistent with the notion that they have higher labour productivity or utilise more skilled labour on average. Their employees are able to communicate with clients in a larger number of languages. Direct exporters, and even more so companies that engage in both direct and indirect exporting, tend to be more innovative, proactive and risk taking, and therefore have higher entrepreneurial orientation.

\section{What makes a successful exporter?}

We examine 14 export-related business practices based on recommendations in the Investment and Development Agency of Latvia 's "Exporting Handbook" and the findings of previous studies about practices that influence export success. We find that these practices are undoubtedly followed to a greater extent by exporters than non-exporters, but the practices are not associated with exporting success. This explains why we see a greater use of the practices by continuing exporters compared to discontinued exporters and recent export start-ups compared to companies that would like to be exporting in the near future, but no substantial differences between exporters that have growing export turnover or an expanding number of export destinations compared to those that have stagnating or declining export activity. The implication of this finding for companies that would like to start exporting in the near future or are currently exporting is that it is advisable to follow export-related business practices, because these practices distinguish exporters from non-exporters. Following export-related business practices will not, however, be sufficient to make a company a successful exporter.

\section{What then makes a successful exporter?}

Our results suggest that successful exporters (measured in terms of positive export turnover growth or export destination expansion) are associated with increasing levels of productivity, tend to be larger companies, and have greater innovativeness, proactiveness and risk taking, i.e., possess a stronger entrepreneurial orientation. Although it is not possible to provide strong evidence on causality within the framework of this study, if companies wish to imitate the profile of a successful exporter then they should consider focussing on increasing productivity, entrepreneurial orientation (innovativeness, proactiveness, risk taking), and generating growth.

\section{What obstacles are faced by exporters and how can policymakers promote exporting?} Latvian exporters feel that the most severe obstacle to exporting is strong price competition in foreign markets. This suggests that relatively low productivity in Latvian companies or relatively high wages/prices compared to trade partners are likely to be significant contributors to the lack of aggregate export turnover growth noted earlier. Therefore, policymakers that consider exports a priority should focus on raising the international competitiveness of Latvian companies, for example by facilitating further adjustment of price/wage levels relative to trade partners or by undertaking policy measures aimed at increasing productivity. Factors such as legal barriers, customs requirements, breakage/spoilage, and a lack of information about the exporting process or about potential export markets play a considerably less important role as obstacles. Companies that hope to start exporting in the near future face similar obstacles to current exporters (strong price competition, working capital requirements, lack of contacts, trust issues), but also face the additional challenges of meeting start-up costs and building proficiency among staff members in the languages spoken in the target export markets. 
Why do some companies cease exporting and other companies never export? The majority of companies that discontinue exporting (58\%) do so due to inability to sustain international competitiveness, sometimes phrased as tough competition in the foreign market, other times as increasing costs of production such as wages. This reinforces the conclusion that productivity and competitiveness are considerable constraints to Latvian exports. An overwhelming majority of companies that have no desire to export state that this is because their product or service is not suitable for export or that they have sufficient demand for the product in the domestic market.

\section{References}

Beņkovskis, K., 2012, Competitiveness of Latvia's exporters, Baltic Journal of Economics $12,17-45$

Katsikeas, C.S., N.F. Piercy, and C. Ioannidis, 1996, Determinants of export performance in a European context, European Journal of Marketing 30, 6-35.

Laaser, C.-F., and K. Schrader, 2005, Baltic trade with Europe: Back to the roots?, Baltic Journal of Economics 5, 15-37.

Obiora, K.I., 2009, Decoupling from the East toward the West? Analyses of spillovers to the Baltic Countries, International Monetary Fund Working Paper WP/09/125.

Rauch, A., J. Wiklund, G. Lumpkin, and M. Frese, 2009, Entrepreneurial orientation and business performance: An assessment of past research and suggestions for the future, Entrepreneurship Theory and Practice 33, 761-787.

Zou, S., and S. Stan, 1998, The determinants of export performance: A review of the empirical literature between 1987 and 1997, International Marketing Review 15, 333-356. 